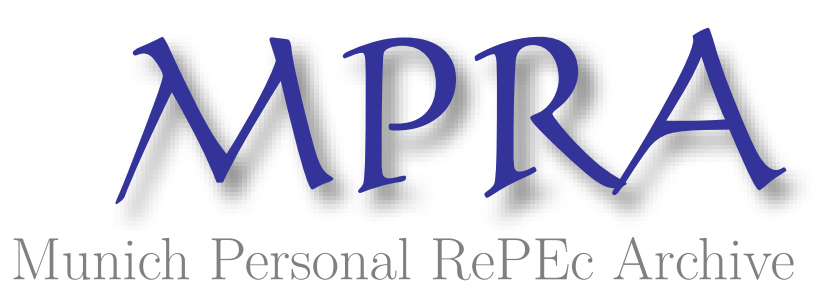

\title{
What twenty years of regulations have to say about MAs of U.S. banks?
}

Leledakis, George and Mamatzakis, Emmanuel and

Pirgiotakis, Manos and Travlos, Nikolaos

AUEB, University of Sussex, University of Surrey

27 November 2017

Online at https://mpra.ub.uni-muenchen.de/82977/

MPRA Paper No. 82977, posted 04 Dec 2017 07:24 UTC 


\title{
What twenty years of regulations have to say about M\&As of U.S. banks?
}

\author{
Leledakis $^{\mathrm{a}}$ George N., Emmanuel C. Mamatzakis ${ }^{\mathrm{b}}$, Emmanouil G. Pyrgiotakis ${ }^{\mathrm{c}}$ \\ and Nickolaos G. Travlos ${ }^{\mathrm{d}}$
}

December 2017

\begin{abstract}
We extend the U.S. bank M\&As literature by examining announcement returns for acquisitions of both listed and unlisted targets by U.S. banking firms for a long period of time from the eighties till to date. Over these decades there have been implemented several regulation changes, notably the Dodd-Frank Act that would be of interest to examine whether they have any impact, and if indeed they have to which direction, on value creation in M\&As in the U.S. banking industry. Contrary to the conventional wisdom that bidding banks lose upon the announcement of a merger, we find positive abnormal returns for these firms that choose to acquire privately-held targets. Further, returns for acquirers in private offers do not depend on the method of payment, legislative changes, size, or geographical scope. However, we find that the use of a financial advisor on the part of the bidder can better explain the variation in abnormal returns for such offers. Our results are not influenced by any unobserved bidder-specific component or sample selection issues.
\end{abstract}

JEL Classification: G14, G21, G34.

Keywords: Mergers and Acquisitions; Regulations, Banks; Value Creation.

${ }^{\mathrm{a}}$ Department of Accounting and Finance, Athens University of Economics and Business, Greece, e-mail: gleledak@aueb.gr, ${ }^{\mathrm{b}}$ School of Business, Management and Economics, Jubilee Building, Falmer BN1 9SL, University of Sussex U.K., e-mail: e.mamatzakis@sussex.ac.uk ${ }^{c}$ Department of Accounting and Finance, Athens University of Economics and Business, Greece, e-mail: manospirg@aueb.gr, ${ }^{\mathrm{d}}$ Surrey Business School, University of Surrey, U.K, e-mail: n.travlos@surrey.ac.uk. 


\section{Introduction}

The U.S. banking industry has experienced intense consolidation in the previous decades. Financial innovation and deregulation fostered successive bank merger waves. However, empirical research fails to provide conclusive evidence that the U.S. bank mergers create value for the bidding firms' shareholders. In fact, Cornett and De (1991), Houston and Ryngaert (1994), DeLong (2001), DeLong and DeYoung (2007), Brewer and Jagtianni (2013), among others, document marginally negative or insignificant market reaction for bidding firms at the merger announcement date. These findings contradict the consensus view, that mergers and acquisitions (M\&As) occur for synergies. Notably, all of these studies examine M\&As between listed firms, despite the fact that the majority of acquisitions by U.S banks involves unlisted targets.

Motivated by the lack of empirical evidence for bank acquisitions of nonpublic firms, we attempt to shed light on this unexamined issue and investigate whether banks could gain if they choose to acquire unlisted targets. Therefore, we use a large and comprehensive sample of 2,178 M\&As of public, privately-held, and subsidiary targets by U.S. banks announced over the period 1984 to 2015 . Our initial findings indicate the existence of a "listing effect" in our sample, which is consistent with prior literature on non-financial M\&As (Chang, 1998; Fuller et al, 2002; Officer et al., 2009; Netter et al., 2011; Arikan and Stulz, 2016; Brander and Egan, 2017): bidders acquiring listed targets achieve negative announcement abnormal returns whereas bidders acquiring standalone private companies earn significant abnormal returns upon the merger announcement.

Importantly, when we examined the sources of this difference in market reaction between listed and unlisted bids, we find results that deviate from the empirical findings in non-financial M\&As. Contrary to Chang (1998), Fuller et al. (2002), Officer et al. 
(2009), and Netter et al. (2011), we do not find empirical support for any method of payment effects for private offers. In fact, when banks acquire private targets, announcement abnormal returns are positive and significant regardless of the method of payment. In addition, results for subsidiary targets do not suggest any difference in market reaction on whether the deal is financed with cash, stock, or a combination of cash and stock. Consequently, our empirical findings do not support the various hypotheses that have been profound to explain this phenomenon, such as the monitoring activities by target shareholders in equity offers, or the mitigation of the target firm's uncertainty in stock-swap acquisitions.

Next, we examine if the use of a financial advisor on the part of the bidder may contribute to the pattern of abnormal returns in private offers. By definition, uncertainties regarding the valuation of financial firms are fundamentally different than for non-financial firms. Therefore, we hypothesize that the use of a financial advisor may help the acquirer to mitigate the risks from the uncertain valuation of the target firm, especially in private offers, where information regarding the target is not widely available. To test this hypothesis, we collect bidder advisor date for our sample, which restricts the number of useable observation to 1,055 . Interestingly, our findings indicate that the use of a financial advisor by the bidding bank has an adverse effect on announcement period returns in public and private offers. More specifically, in public bids, abnormal returns are on average $1.34 \%$ lower when the bidding firm employs a financial advisor. By contrast, when bidding banks use financial advisory services in private offers, they experience approximately $2.06 \%$ larger average abnormal returns. Results for subsidiary targets are inconclusive. Hence, we conjecture that advisory services are more meaningful in private offers, since the valuation of the target firm incorporates increased uncertainty. Finally, we test for the effect of the bidder advisor 
reputation on bidder returns, and we find a negative or at best insignificant relationship between the use top-tier advisors and announcement period returns for all types of mergers (McLaughlin, 1992; Hunter and Jagtianni, 2003; Ismail 2010; Graham et al., 2015).

We also consider the possibility that there could be a bidder-specific driver of acquisition success that can better explain the variation of abnormal returns across the several types of M\&As (Golubov et al., 2015). We find that even after the inclusion of bidder fixed effects in our regression analyses, banks that acquire private firms and employ financial advisors enjoy the highest possible abnormal returns. Further, we also control for the possibility that the choice of the target firm is endogenously determined. In order to address this issue, we employ the two-stage procedure outlined by Heckman (1979), and we find that all our results continue to hold after controlling for potential endogenous sample selection.

Our study is related to the extensive literature on the listing effect on non-financial U.S. mergers (Chang, 1998; Fuller et al., 2002; Officer, 2009; Netter et al., 2011, Arikan and Stulz, 2016). We apply a similar process in a different context- M\&As by U.S. banking firms- and find, a significant difference in market reaction between public and nonpublic bids. Further, our study is also related to the literature on the interaction between bidder financial advisors and announcement period gains (Servaes and Zenner, 1996; Hunter and Jagtiani, 2003; Golubov et al., 2012; Graham et al., 2015). Our empirical results indicate that bidding banks could realize positive abnormal returns as long as they acquire privately-held firms, and use financial advisory to resolve potential uncertainties regarding the target firm's valuation. These findings contradict the consensus view that banks lose upon the announcement of a merger (Houston and Ryngaert, 1994; DeLong, 2003; Gupta and Misra, 2007, Brewer and Jagtiani, 2013). 
To the best of our knowledge, this study is the first to examine bank acquisitions under this perspective.

The remainder of the paper is organized as follows. Section 2 reviews the related literature and develops the implications of the prior empirical findings in our study. Section 3 details the data collection for the empirical analysis. Sections 4 and 5 present the univariate and multivariate empirical analysis, respectively. Finally, Section 6 concludes the paper.

\section{Related background and research questions}

There is a plethora of studies examining the relation between bidder returns and the target firm's listing status in non-financial U.S. M\&As. Chang (1998), Fuller et al., (2002), Moeller et al. (2004), Officer et al. (2009) all find positive abnormal returns for acquirers of private firms and subsidiaries. The authors also document a positive relation between bidder returns and equity financing in such deals.

There are several explanations for the larger returns to acquiring firms when the target is unlisted. Chang (1998) suggests that equity offers for private firms tend to create outside blockholders that could serve as effecting monitors of managerial performance. Fuller et al. (2002) document similar results and illustrate tax considerations benefits as an alternative explanation for the higher abnormal returns for stock offers relative to cash offers for private targets. Moeller et al. (2004) outline the importance of the acquiring firm's size in explaining the difference in market reaction between listed and unlisted targets. Acquirers of private targets are more likely to be smaller and pay less for acquisitions than acquirers of public targets. Officer et al. (2009) find a significant positive relation between announcement period returns and stock financing in difficult- 
to-value targets, since stock financing is considered to mitigate information asymmetry about the uncertain value of the target firm. In fact, the effect of target-valuation uncertainty is more evident to acquisitions of nonpublic firms, since private firms are more opaque in comparison to publicity traded companies.

Recent empirical work in M\&As also documents a significant difference in market reaction between listed and unlisted targets. John et al. (2010) highlight the importance of the target country's investor protection in determining the magnitude of the listing effect on bidder gains. By using a large sample of cross-border acquisitions of public and private firms by U.S. bidders, the authors find that in high investor protection target countries bidder abnormal returns are significantly negative for public targets and significantly positive for private targets. Netter et al. (2011) utilize a large sample of non-financial U.S. acquisitions of both public and private firms, and find comparable results with previous studies: in stock offers, bidders realize the lowest returns when the target is publicly-traded and the highest when the target is a private firm. Arikan and Stulz (2016), show that acquiring firms have better growth opportunities and realize higher announcement returns in acquisitions of nonpublic firms. Brander and Egan (2017) examine acquisition of both public and private firms under the winner's curse perspective. Their findings indicate a stronger winner's curse in public offers, since the proportion of acquiring firms realizing negative announcement returns is substantially higher in such deals.

It has been documented in the literature that uncertainty in non-financial M\&As constitutes a key element in explaining bidder abnormal returns (Hansen, 1987; Moeller et al., 2007; Officer et al., 2009). In fact, acquirers of more opaque targets experience a larger fraction of total acquisition gains, since they are able to obtain superior information regarding the target firm's value during the due diligence process (Luypaert 
and Van Caneghem, 2017). It is therefore likely, that the use of a financial advisor may help the acquiring firm to gather such information and identify potential synergetic opportunities. In fact, one important aspect of the financial advisory services is to ascertain the informationally opaque target value to the acquiring firm. Servaes and Zenner (1996) found that financial advisors are used in more complex transactions that are characterized by significant asymmetric information.

There is a growing literature that examines the relation between financial advisory services and bidder abnormal returns. Bowers and Miller (1990) found that the choice of a financial advisor constitutes an important determinant of merger gains for acquiring firms. In their more recent studies, Ismail (2010) and Graham et al. (2015) suggest that acquiring firms garner higher abnormal returns when they employ non-top-tier financial advisors, rather than large prestigious investment banks. On the other hand, Golubov et al. (2012) document a positive relationship between advisor reputation and bidder CARs, after controlling for selection bias issues.

All the aforementioned studies focus exclusively on non-financial M\&As. Therefore, it would be interesting to investigate whether such findings have any application in acquisitions by U.S. banks. In our study, we examine whether banking firms could realize positive abnormal returns by acquiring unlisted firms. In addition, we identify if there is any relation between the use of a financial advisor by the acquiring firm and announcement period gains. It is commonly held that financial firms are inherently more opaque than non-financial firms (Wagner, 2007; Kwan and Carleton, 2010). If we assume that information gathering is indeed meaningful to acquiring firms, then it is reasonable to expect that the use of a financial advisor would translate to higher bidder abnormal returns, especially in cases where information regarding the target is not widely available. 


\section{Sample and data}

We collect merger data from Thomson ONE database. Our sample consists of all successful M\&As by U.S. banking firms, with initial bids announced between January 1, 1984 and December 31, 2015. ${ }^{1}$ We retrieve mergers that meet the following criteria:

1. Bidding firms are commercial banks with a three-digit primary SIC code equal to 602 , or bank holding companies with a four-digit primary SIC code equal to 6712.

2. The bidder is publicly-traded. The target is a public firm, a private firm, or an unlisted subsidiary of a public firm.

3. All public firms are listed on NYSE, Amex, or Nasdaq.

4. Bidding firms have available return data on the Center for Research in Security Prices (CRSP) for at least five days around the merger announcement and Compustat data for the year-end prior to the merger announcement.

5. The bidder acquired an interest of above $50 \%$ in the target firm, raising its interest from below $50 \%$ to above $50 \%$.

6. The deal value is disclosed and above $\$ 1$ million.

The criteria result in an initial sample of 2,321 M\&As, where 817 of the targets were listed on an exchange, 1323 were stand-alone private companies, and 181 were subsidiaries of listed firms. We follow Fuller et al. (2002) and we exclude from the sample 110 clustered mergers, where the bidding bank acquired more than one target firms within 5 days, in order to isolate the bidder's abnormal return for a specific merger

\footnotetext{
${ }^{1}$ Barnes et al. (2014) suggest that Thomson ONE data (former SDC) are reliable from 1984 and onward while early 1980 s are not recommended for research.
} 
(24 public targets, 79 private targets, and 7 subsidiary targets). We further eliminate 5 duplicate listings from the sample (1 public target, 4 private targets). Duplicates are defined as instances where the same bidder, target and announcement date are listed more than once in the Thomson ONE database. ${ }^{2}$ Similar to Hagendorff and Vallascas (2011), we also exclude 20 mergers which involved failing institutions, as reported by Thomson ONE ( 2 public targets, 15 private targets, 3 subsidiary targets). Finally, we exclude 8 mergers where data for the method of payment are not available (6 private targets, 2 subsidiary targets). Our final sample consists of 2,178 mergers, where 790 of the targets were listed firms, 1,219 were private companies, and 169 were unlisted subsidiaries of listed firms.

\subsection{Sample statistics}

Table 1 shows the inflation-adjusted (base 2015 dollars) mean value of transaction and the number of mergers per year. The merger sample is segmented based on the target firm's listing status. Evidently, the number and size of M\&As do not increase monotonically through time in each category. Initially, we observe a sharp increase in merger activity in the 1990s, for all three types of mergers. This increase is consistent with Mitchell and Mulherin (1996), who document that the deregulation wave of the 1990s has spurred intense consolidation in the U.S. banking industry. In the new millennium, merger activity experienced a downward trend, and did not peak until the mid 2000s. The 2008 financial crisis led to a further dramatic decrease in the level of banking consolidation. However, in the most recent years, U.S. bank M\&A activity exhibits an increasing trend, following the passage of the Dodd-Frank Act (Leledakis and Pyrgiotakis, 2016).

\footnotetext{
${ }^{2}$ Duplicates emerge from errors in updating Thomson ONE data. In these cases, when new information is available for a M\&A transaction, a new record is created in the database while the previous one still exists.
} 


\section{Insert Table 1 here}

Table 2 reports the distribution of our merger sample by target firm's industry affiliation, using 48-industry classifications from Fama and French (1997). Industries definitions are based on the four-digit primary SIC codes. ${ }^{3}$ We report by industry the number of banks making successful bids for all types of targets, and we further divide the sample based on the target firm's listing status. Interestingly, almost the whole sample $(98.62 \%)$ involves targets within the financial industry, whereas the vast majority of deals (89.39\%) are limited to bank-to-bank mergers.

\section{Insert Table 2 here}

Table 3 provides additional data describing the sample. Panel A reports the mean and median values for deal-specific characteristics of our sample. Transaction value is the total amount of consideration paid by the bidding bank excluding fees and expenses (in 2015 million \$). Not surprisingly, the dollar value of M\&As is much larger for listed targets than private or subsidiary targets. Notably, mergers involving public targets are approximately 22 times larger compared to mergers involving private targets. Days to completion is the number of calendar days between the announcement and effective dates, and serves as a proxy for merger complexity. The length of a merger is larger for deals involving public targets than for deals involving unlisted firms, suggesting that as mergers get larger and more complex, the time to close a deal increases. Following Martin (1996), we group the method of payment into three different categories: (1) Cash payments include combinations of cash, debt, or liabilities. (2) Stock payments include financing with common stock or combinations of common stock and options or

\footnotetext{
${ }^{3}$ Primary SIC codes denote the primary line of business for a company. However, up to ten different SIC codes may be assigned to each firm, based on the lines of business the company is involved. Therefore, a target firm in our sample may be characterized a bank by its primary SIC code, but it could also engage in trading, insurance, or real estate activities.
} 
warrants. (3) Combo financing includes combinations of cash, common stock, debt, preferred stock, convertible securities and methods classified as "Other consideration" by Thomson ONE database. We observe that stock financing is the prevailing method of payment for acquisitions of public and private targets, whereas in the case of subsidiary targets, bidding banks prefer to pay with cash. Lastly, geographical focus is expressed by the percentage of the same state deals.

Panel B of Table 3 reports the mean and median values for bidder-specific characteristics. We provide data on the bidding firm's size (total assets and market value of equity) and profitability. In line with the literature on non-financial firms, the average bidder of public targets is larger compared to the average bidder of private targets. Average bidder profitability, as measured by return on assets (ROA) is 1.04, 1.07 , and 0.99 for listed, private and subsidiary targets, respectively.

\section{Insert Table 3 here}

\subsection{Financial advisor data}

In order to test the relation between bidder abnormal returns and financial advisory services we download financial advisor data for the bidding banks of our sample. More precisely, we collect information on whether or not any advisors were used by the bidding firm, number of advisors used and advisor's full name, from Thomson ONE database. For our whole sample of 2,178 M\&As, we identified 1,055 mergers with complete information about bidder financial advisors (540 public targets, 443 private targets, and 72 subsidiary targets). Out of the 1,055 sampled deals, 861 were advised by at least one investment bank, and 194 deals did not involve any financial advisors on the part of the bidder (in-house deals). 
We also control for the financial advisor's reputation, to test whether top-tier investment banks are perceived to provide better services in bank acquirers than nontop-tier advisors. Hence, we download financial advisors league tables from Thomson ONE database for deals announced and completed during the period January 1984 to December 2015. Table 6 presents financial advisor rankings according to the dollar value of transaction handled by the advisor during the sample period. Interestingly, the top-11 advisors are the same in both announced and completed deals' rankings. Following Fang (2005), we classify advisors into two tiers: the top-8 investment banks are defined as "top-tier" and all other financial advisors as "non-top-tier". The use of this binary classification is preferable econometrically, since the use of a continuous variable would imply that the separate tiers should have a constant effect on bidder abnormal returns. The top- 8 financial advisors are: Goldman Sachs \& Co, Morgan Stanley, Bank of America Merrill Lynch, JP Morgan, Citi, Credit Suisse, Barclays, and Lazard. Most of these investment banks appear in league tables of prior studies (Rau, 2000; Hunter and Jagtiani, 2003; Golubov et al., 2012). Hence, we suggest that financial advisors' reputation is relatively stable overtime.

In order to correctly assign the reputation of each financial advisor, we follow Golubov et al. (2012), and we account for the M\&As between financial advisors. For example, Bank of America was not a top-tier financial advisor prior to the acquisition of Merrill Lynch in 2008. Hence, mergers advised by Bank of America before 2008 are classified as advised by a non-top-tier financial advisor. Finally, in case a bidding bank had employed multiple financial advisors, the deal is classified as advised by a top-tier advisor if at least one of the advisors belongs to the top- 8 group (Servaes and Zenner, 1996).

Insert Table 4 here 


\section{Univariate Analysis}

We use the standard event study methodology, outlined by Brown and Warner (1985), to evaluate bidder gains around the merger announcement dates. We estimate cumulative abnormal returns (CARs) over a five-day event window, centered on the announcement date $(-2,+2)$ using the market adjusted return model: ${ }^{4}$

$$
A R_{i, t}=R_{i, t}-R_{m, t}
$$

Where $R_{i, t}$ is the return for stock $i$ on day $t$ and $R_{m, t}$ is the market return on the CRSP NYSE/Amex/Nasdaq value-weighted index on day $t$. We do not estimate market model parameters over a time interval prior to the merger announcement to account for the possibility that a bidding bank had announced onether merger at some point during the estimation period (Fuller et al., 2002). ${ }^{5}$ We evaluate the statistical significance of our results based on the standardized cross-section test of Boehmer et al. (1991). This procedure corrects for potential increases in the variance of abnormal returns, commonly found in event studies. Further, to account for the non-normal distribution of the security returns, we test the statistical significance of the median values by using the Wilcoxon signed-rank test.

Table 4 presents the mean CARs for bidding banks classified by the target firm's listing status and method of payment. The first column of Table 4 reports CARs for the full sample of bidders. Consistent with prior empirical findings, bidding banks realize negative abnormal returns upon the announcement of a merger. However, when we

\footnotetext{
${ }^{4} \mathrm{We}$ also examined other event windows frequently used in the literature $(-1,+1),(-5,+1),(-10,+1),(-$ $10,+10),(-1,+10),(-30,+5)$. Results remained qualitatively similar.

${ }^{5}$ To ensure robustness of our results we have also estimated CARs using the market model and the mean adjusted returns model. Results remained unchanged.
} 
differentiate returns based on the method of payment we observe that cash offers experience insignificant results, whereas mergers financed with any type of stock realize statistically negative abnormal returns. Segmenting by the type of the target firm, we are able to extract more conclusive results. In public bids, the average abnormal return for bidding firms is $-1.45 \%$, and statistical significant at $1 \%$ level (Cornett and De, 1991; Houston and Ryngaert, 1997; DeLong and DeYoung, 2007). Again, returns for the cash offers are indistinguishable for zero. However, in stock or combination offers, abnormal returns are negative and significant in the scale of $-1.61 \%$ and $-1.63 \%$, respectively. The median abnormal returns for these deals are $-1.37 \%$ and $-1.64 \%$, respectively, and the Wilcoxon signed-rank test is significant in both cases. Therefore, in public bank M\&As, equity offers translate to a negative market reaction (Travlos, 1987). On the contrary, in private bids, the average bidding bank earns a $0.58 \%$ abnormal return, which is statistical significant at $1 \%$ level. These results suggest that bidders of privately held targets experience approximately $2.03 \%$ larger abnormal returns compared to bidders of publicly traded targets, on average. This difference is statistical significant at $1 \%$ level $(t=9.84)$. Interestingly, in private offers, bidder abnormal returns are positive and significant regardless of the method of payment: cash $(0.61 \%)$, stock $(0.56 \%)$, and combination $(0.57 \%)$. Medians are significant in all cases except from equity offers. In the case of subsidiary targets, the bidders CARs are insignificant for all groups. However, the difference in market reaction between public and subsidiary offers is also significant at $1 \%(t=4.17)$. Overall, our results support the existence of a "listing effect" in M\&As between U.S. banks and domestic unlisted targets. Henceforth, in our discussion of results, we focus on mean CARs, since mean and median CARs tell the same story.

\section{$\underline{\text { Insert Table } 5 \text { here }}$}




\subsection{Explanations of the listing effect in bidder CARs}

The majority of the U.S. studies that examine the listing effect in M\&As attribute the difference in market reaction between public and private bids to method of payment effects. The monitoring hypothesis outlined by Chang (1998), suggests that acquisitions of closely-held private firms result in the creation of outside blockholders that act as effective monitors of acquirer's managerial performance. Consequently, when bidding firms pay with common stock for private targets, they experience a positive revaluation of their share price. Fuller et al. (2002) document that equity offers in private bids could result in more positive abnormal returns, since the shareholders of the target firm would share any potential risks from overvaluation. Accordingly, Officer et al. (2009) demonstrate that stock offers for difficult-to-value targets translate to positive bidder announcement returns in acquisitions of unlisted targets. Apparently, all these hypotheses predict that, in acquisitions of privately-held targets, bidder CARs should be significantly larger when firms pay with stock instead of cash. Our results however, are inconsistent with these findings. In particular, bidding banks realize positive abnormal returns in private offers, irrespective of the method of payment (differences across subsamples of private targets are insignificant). Furthermore, in the case of subsidiary targets, abnormal returns do not differ for cash, equity, or mixed offers. Hence, we posit that the traditional explanations for the listing effect do not account for the difference in market reaction between listed and unlisted targets, for bank acquirers. For example, the monitoring hypothesis, one of the most common explanations for the listing effect is non-financial U.S. mergers, assumes that private firms are familyowned or closely-held. However, in our sample, Thomson ONE reports only 3 cases 
where private target firms were family-owned. ${ }^{6}$ It is therefore unlikely that the ownership structure of the target firm would have a monitoring effect in the case of M\&As by U.S. banks.

One alternative explanation for the listing effect assumes limited competition for the privately-held targets, due to the higher costs of obtaining accurate information. In a limited competition environment, bidders may realize positive abnormal returns, since the likelihood of underpayment is higher (Chang, 1998). In addition, James and Wier (1987), Cornett and De (1991), and others, document that the number of bids per target firm (proxy for competition) relates to statistically lower announcement returns, since the winning firm might overpay to win the bidding war. However, as shown in Table 3 , the vast majority of target firms receive only one public bid: public targets $(98.10 \%)$, private targets $(99.92 \%)$, subsidiary targets (100\%). Hence, bidding banks face almost no competition in acquiring either listed or unlisted targets. It is therefore unlikely that the limited competition hypothesis can explain the listing effect in M\&As by U.S. banking firms.

Another strand of the M\&As literature suggests that merger gains may be capitalized before the official merger announcement. For example, Schipper and Thomson (1983) find significant bidder gains in the pre-acquisition period, and attribute their findings to potential leakage of information. In this case, measuring abnormal returns at the announcement date may underestimate the market reaction for the transaction, since such leakage would show-up in the pre-announcement bidder returns. Hypothetically, this is a more likely scenario in deals than involve two listed firms, where information regarding the merging firms is more widely available, than in acquisitions of unlisted

\footnotetext{
${ }^{6}$ A target is characterized as "family-owned" if at least a family, a group of families, or a non-founding chairman controls $20 \%$ of the firm.
} 
firms. Hence, the difference in announcement abnormal returns between listed and unlisted bids may not reflect a difference in wealth creation, since merger gains for public offers might have been ex-ante capitalized and impounded in the stock price. To account for this possibility, we examine if there is a run-up in the bidding firm's stock price, emanating from any potential leakage of information regarding the acquisition. Following Faccio et al. (2006) we compute pre-announcement abnormal returns over the window $(-15,-3)$. Over this interval, abnormal returns are positive for all types of mergers, but significant only for the private offers. More precisely, bidder CARs are: $0.10 \%$ for public targets, $0.46 \%$ for private targets, and $0.63 \%$ for subsidiary targets. Therefore, these results are inconsistent with the assumption that prior capitalization of merger gains accounts for the listing effect in our sample. ${ }^{7}$

\subsection{Regulatory effects on bidder CARs}

The U.S. banking industry is accustomed to legislative tsunamis. Federal legislations usually incorporate several regulations governing bank merger activity. Prior studies have outlined the important effect of regulatory changes on merger wealth gains (Carow and Heron, 1998; Becher, 2000, 2009; Filson and Olfatti. 2014; Leledakis and Pyrgiotakis, 2016). Therefore, we test whether these legislative changes could explain the difference in market reaction between public and nonpublic bids.

During our sample period, four consecutive pieces of federal legislation made substantial changes in the permissible bank merger activity. Initially, the Financial Institutions Reform, Recovery and Enforcement Act of 1989 (FIRREA), allowed commercial banks to acquire failed thrift institutions. The Riegle-Neal Interstate

\footnotetext{
${ }^{7} \mathrm{We}$ also examine deals that began as a rumor. Thomson ONE identifies a rumor for possible acquisition for 26, 9, and 8 acquisitions of public, private, and subsidiary targets, respectively. Given the small number of deals in each category, it is quite unlikely that rumors of acquisitions could explain the listing effect in our sample.
} 
Branching and Efficiency Act of 1994 eliminated all restrictions to interstate branching, and enabled banks to expand nationwide through M\&As. Furthermore, the GrammLeach-Bliley Financial Modernization Act of 1999 (GLBA) effectively removed all the barriers that prohibited commercial banks from expanding into the securities and insurance industries. On the contrary, the Dodd-Frank Wall Street Reform and Consumer Protection Act of 2010 (DFA) raised the barriers to consummating merger transactions, and imposed stricter concentration limits to prevent future consolidation among large, systemically important financial institutions.

We follow Gupta and Misra (2007), and we disaggregate our sample in separate regulatory periods, according to the dates when provisions of each piece of legislation became effective: ${ }^{8}$ Pre-FIRREA period (January 1984 to September 1989), FIRREA period (October 1989 to June 1997), Riegle-Neal period (July 1997 to March 2000), Gramm-Leach-Bliley period (April 2000 to June 2010), and Dodd-Frank period (July 2010 to December 2015).

Table 5 summarizes bidder abnormal returns for different regulatory periods, segmented by the target firm's listing status. For the whole sample of mergers, we observe that returns vary significantly across regulatory periods. More specifically, mean CARs are negative and significant in the Pre-FIRREA, FIRREA, and Riegle-Neal periods, while in the Gramm-Leach-Bliley period, bidding banks realize a mean abnormal return of $0.10 \%$, which is statistical significant at $5 \%$. After the enactment of the Dodd-Frank Act, bidders experience significant wealth gains, in the scale of $0.79 \%$, on average (Leledakis and Pyrgiotakis, 2016). For public bids, results are consistent with prior U.S. bank M\&As studies: bidder CARs are negative and significant at $1 \%$

\footnotetext{
${ }^{8}$ Alternatively, we classified the sample according to the dates the separate legislations were signed into law. Results were qualitatively similar.
} 
level, ranging from $-2.80 \%$ in the pre-FIRREA period to $-1.00 \%$ in the GLBA period. In the Dodd-Frank period however, abnormal returns for bidding banks are indistinguishable from zero. For private offers, abnormal returns are positive in all but the pre-FIRREA period, but significant only in the FIRREA and DFA periods. Results for subsidiary targets are insignificant, regardless of the regulatory changes.

These results indicate that legislative changes could have a significant impact on bidder abnormal returns. However, we are mostly interested in examining whether the difference in market reaction between public and nonpublic bids persists across regulatory periods. The last two columns of Table 5 report the differences between the means and medians for private and public targets, and subsidiary and public targets, respectively. ${ }^{9}$ Our results indicate that bidder abnormal returns are larger for private and subsidiary targets than for public targets for all regulatory periods, and the magnitude of these differences does not vary substantially overtime. In terms of statistical significance, differences between means and medians for private and public targets are significant at $1 \%$ level in all regulatory periods. For subsidiary targets, differences are abnormal returns significant in all but the DFA period. Thus, the interpretation of these results is that the listing effect persists through time and is not due to any legislative changes in the U.S. banking industry.

\section{Insert Table 6 here}

\subsection{CARs at the completion date}

\footnotetext{
${ }^{9}$ Significance for the difference between mean CARs and median CARs is based on the $t$-test and on the Mann-Whitney test, respectively.
} 
All the prior empirical work we have documented so far focuses on announcement period returns, implying that all expected price reactions should occur at the announcement of a bid. However, in practice, not all announced mergers are finally completed. An important feature of the financial sector is that regulatory approval is mandatory for the completion of a transaction. Regulators may reject an application if the acquisition does not satisfy the public benefit criteria, or exceed several concentration limits (Desai and Stover, 1983).

It is therefore likely that the probability of success may influence the market reaction upon the announcement of a proposed merger. In fact, the uncertain outcome may induce investors to postpone their reaction at a time where the bidder intention to acquire is indeed materialized. We explore whether the likelihood of an acquisition success is higher for unlisted targets than for listed targets. In this case, the announcement abnormal returns for the public bids could be downward biased compared to the returns for private bids. However, abnormal returns at the deal completion date may be higher for public than for private bids. As a result, the listing effect in announcement period gains may be explained by a difference in the proportion of successful acquisitions between the separate types of targets.

We base the assumption of a different probability in acquisition success for listed and unlisted target on two main arguments. Firstly, the Williams Act of 1968 mandates information disclose and waiting periods for acquisitions of publicly-traded firms, whereas such requirements are not applicable to acquisitions of privately-held firms. Hence, acquisitions of private targets may be announced when completed (Officer et al., 2009). Secondly, acquisitions of public firms are typically larger, suggesting that regulatory approval is a less likely scenario. 
In the spirit of Faccio et al. (2006), we identify acquisitions that were announced as completed transactions at the initial announcement date. From our whole sample of 2,178 M\&As, only 79 deals where announced when completed (1 public target, 64 private targets, 14 subsidiary targets). Thus, for the remaining 2,099 deals there was uncertainty regarding the successful completion of the proposed transaction (789 public targets, 1,155 private targets, 155 subsidiary targets). Further, we identified 206 M\&As that were announced but not completed during the examination period (103 public targets, 96 private targets, 7 subsidiary targets). Accordingly, the probability of success for a public bid is $(789 /(789+103))=88.45 \%$, the probability of success for a private bid is $(1,155 /(1,155+96))=92.33 \%$, and the probability of success for a subsidiary bid is $(155 /(155+7))=95.68 \%$. Consistent with our prediction, the probability of a successful acquisition in the case of a listed target is smaller relative to an unlisted target, albeit the differences are small.

At last, we examine whether these differences in acquisition success probabilities translate into differences in bidder abnormal returns at deal completion dates. In line with announcement period returns, we estimate bidder CARs over a five-day window, centered on the completion date. We include in the analysis only the bidders of the 2,099 M\&As in which there was uncertainty about the success of the acquisition. ${ }^{10}$ In fact, CARs are positive for all types of mergers, but significant only for public offers. More specifically, bidder completion CARs are: $0.32 \%$ for public targets, $0.10 \%$ for private targets, and $0.47 \%$ for subsidiary targets. These results indicate that market participants do indeed reward bidding banks when they complete an acquisition of a public firm. However, differences between public and private offers, and public and subsidiary offers are insignificant, suggesting that the market reaction at the deal

\footnotetext{
${ }^{10}$ Results were qualitatively similar for the whole sample of 2,178 M\&As
} 
completion date does not offset the difference in market reaction between listed and unlisted targets at the announcement of such bids.

\subsection{The role of financial advisors}

Panel A of Table 7 presents the bidder CARs for the sample of the 1,055 M\&As, segmenting by the target firm's listing status. Apparently, the results are consistent with the listing effect analyzed previously in this section, since bidder CARs in acquisitions of unlisted targets are significantly larger than in acquisition of listed targets. ${ }^{11}$ In Panel B we partition the sample based on whether or not the bidding banks had used a financial advisor. For the whole sample of 1,055 mergers we find that the use of an advisor does not affect announcement abnormal returns, since returns in both cases are negative and significant but their difference is not statistical significant (Servaes and Zenner, 1996). However, by segmenting again based on the target firm's listing status we are able to extract more conclusive results. In particular, in-house deals for public offers produce insignificant abnormal returns, whereas when an advisor is used, public bids experience a mean abnormal return in the scale of $-1.90 \%$, which is statistical significant at $1 \%$ level. On the contrary, in acquisitions of privately-held targets, we observe a different pattern: for in-house deals, average abnormal returns are $-0.59 \%$ and marginally significant, whereas when an advisor is used, bidder CARs are $1.47 \%$, and statistical significant at $1 \%$ level. Results for subsidiary targets are inconclusive. Therefore, we observe an adverse effect of financial advisors on bidding banks' cumulative abnormal returns for public and private offers. Our findings suggest that financial advisory is more meaningful to the acquisitions of privately-held targets, since private financial firms should be more opaque than their publicly-traded rivals. Lastly,

\footnotetext{
${ }^{11}$ In addition, the method of payment does not influence bidder CARs in the subsample of 443 private offers. In particular, bidder CARs are $0.84 \%, 0.74 \%$, and $1.13 \%$, for cash, stock, and combination offers, respectively.
} 
Panel C of Table 7 details CARs based on the financial advisors' reputation. Similar to McLaughlin (1992), Rau 2000, Ismail (2010), and Graham et al., (2015), announcement abnormal returns to bidders advised by top-tier advisors are lower than those earned non-top-tier advised bidders.

\section{Insert Table 7 here}

Overall, we conjecture that the use of financial advisors could at least partly explain the listing effect in acquisitions by U.S. banks. In fact, when bidding banks employ financial advisors, they experience approximately 3.37\% higher abnormal returns on average when the target is privately-held than when the target is publicly-traded. The difference is statistical significant at $1 \%$ level $(t=7.90)$.

\section{Multivariate analysis}

In the previous section, we analyze the bidding banks' abnormal returns using univariate analysis. The results of the univariate analysis indicate considerable variation in bidder abnormal returns. Therefore, we perform multivariate tests of the determinants of bidder CARs, to ensure the robustness of the aforementioned results. In our regression, we estimate bidder returns as a function of deal- and bidder-specific characteristics, frequently used in the literature. The dependent variable is the five-day bidder CARs centered on the announcement date. All independent variables are defined in the Appendix.

Hence, we conduct OLS regressions for the whole sample of 2,178 mergers and for three separate subsamples based on the target firm's listing status. For each category we run several models, to account for the differences in usable observations between 
the initial sample and the sample where financial advisor data are used. Further, in order to reduce a possible effect of outliers, we winsorize all the continuous variables at $1 \%$ and $99 \%$ level. We control for heteroskedasticity by estimating robust standard errors, following White (1980). Correlation coefficients of the independent variables indicate a weak to moderate degree of linear relationship among the several sets of variables. ${ }^{12}$ Hence, to investigate whether multicollinearity is present in our models, we calculate the variance inflation factors (VIFs) for each independent variable in each regression. In general, VIF values greater than 10 may merit further investigation. In our case, mean VIFs range from 1.89 to 3.94 , suggesting that multicollinearity should not be a problem in our regression analysis.

\subsection{Regression analysis results}

Table 8 presents the results of our multivariate regressions for all, public, private, and subsidiary acquisitions, respectively. The first three columns illustrate results for the whole sample, irrespective of the target firm's listing status. In all three models, the coefficients of Private and Subsidiary are positive and statistical significant. The magnitude of their coefficients suggests that: (1) the average acquisition of a privatelyheld firm earns a $1.5 \%$ in model 1 and a $2 \%$ in models 2 and 3 larger abnormal return than the average acquisition of a public firm, and (2) the average acquisition of a subsidiary earns a $1.2 \%$ in models 1 and 2 and a $1.3 \%$ in model 3 larger abnormal return than the average acquisition of a public firm. These results are in line with prior studies that document a listing effect in non-financial U.S M\&As (Fuller et al. 2002; John et al 2010). Consistent with Officer et al. (2009), Bidder idiosyncratic volatility has a significant positive effect on bidder CARs in models 1 and 3. In unreported results we

\footnotetext{
${ }^{12}$ The highest correlation coefficient is 0.56 (in absolute value) between Bidder Size and RelSize, for the subsample of 1,291 private targets.
} 
also included an interaction term of Volatility with Stock, with no substantive changes in our results. ${ }^{13} \mathrm{~A}$ handful of the remaining independent variables bear statistical significant coefficients in the regressions for the whole sample. The coefficient of Combo is negative and significant in models 1 and 3 , suggesting that combination offers translate to lower bidder abnormal returns. RelSize is negative and significant in model 1, but loses significance as financial advisor data are included in the analysis. The negative coefficient of Pooling indicates that when bidding banks use the purchase method to incorporate the target into their books, they experience larger abnormal returns. Coefficients for the regulatory dummies are all positive, but significant for the FIRREA, GLBA, and DFA period in model 1, and only GLBA and DFA periods in model 3, respectively. These findings indicate that bidder abnormal returns were significantly larger for bids occurring during these specific regulatory periods, compared to the Pre-FIRREA period.

Models 4 to 6 report regression results for the subset of publicly-traded targets. Consistent with the results for the whole sample, combination offers relate to a negative market reaction in acquisitions of public targets. In addition, RelSize is negative and significant in model 4, suggesting that bidder's returns decrease with the relative size of the target in public acquisitions (Jensen and Ruback, 1983; Travlos, 1987). Volatility is positive and significant in model 4 , albeit loses significance with the addition of the financial advisor data. On the other hand, Pooling has a negative and statistical significant coefficient in all models, implying that the purchase method is superior to the pooling accounting method in terms of bidder CARs, for public bids. Furthermore, the variable Advisors is negative, and statistical significant in both models 5 and 6 . The

\footnotetext{
${ }^{13}$ Moeller et al. (2007) find a negative relationship between bidder CARs in public bids financed with stock and bidder idiosyncratic volatility.
} 
magnitude of its coefficients indicate that in public offers, bidders who use financial advisors experience $-1.2 \%$ in model 5 , and $-1.7 \%$ in model 6 , lower abnormal returns than bidders of in-house deals, on average. Lastly, coefficients for FIRREA, GLBA, and DFA, suggest that these regulatory periods had a significantly positive effect on bidder CARs, compared to the Pre-FIRREA period (Gupta and Misra, 2007, Leledakis and Pyrgiotakis, 2016).

Results for the private offers are similar to what we have found with the univariate analysis. The insignificant coefficients of Stock and Combo in all three models suggest that method of payment does not influence bidder returns in acquisitions of privatelyheld targets. This finding contrasts the traditional explanation of the listing effect in non-financial U.S. mergers, which suggest that when bidders pay with stock in private offers they experience larger abnormal returns (Chang, 1998). Consistent with Fuller et al. (2002), we document a different relationship between bidder returns and the relative size of the target for public and private bids. In particular, RelSize is positive and significant in both models 7 and 9, implying that the larger the target relative to the bidder in private offers, the larger the abnormal returns upon the announcement of the merger. As expected, the coefficient of Advisors in model 8 is positive and significant at $1 \%$ level. This suggests that in private offers, bidders who employ financial advisors earn a mean abnormal return of $1.6 \%$ larger than bidders of in-house deals. We therefore observe an adverse effect of financial advisors between public and private bids. Financial advisory services, such information gathering and processing should be more valuable in private acquisitions, since privately-held financial firms would be inherently more difficult to value than their publicly-traded counterparts. In model 7 , the coefficients for the regulatory dummies are similar to the ones reported for the public bids. However, when advisor data are added, all regulatory dummies lose 
significance, while the coefficient for the Advisors dummy remains significant. Finally, regressions 10 to 12 produce inconclusive results, suggesting that the traditional determinants of bidder abnormal returns do not explain the variation in bidding bank CARs for acquisitions of subsidiary targets.

Interestingly, our results suggest that the size of the acquirer does not have a significant impact on the market reaction at the announcement of the merger. ${ }^{14}$ This findings contrast Moeller et al. (2004), who document that larger acquirers experience smaller abnormal returns. Houston and Ryngaert (1994), and DeLong (2001), support that geographical focus is associated with higher abnormal returns in bank mergers. In our regression however, we find weak evidence of any relation between geographical focus and bidder CARs. Similar to Becher and Campell (2005), we do not find any empirical support that prior bidder performance (ROA), affects merger gains. Lastly, our evidence shows an insignificant relation between bidder advisor reputation and announcement returns (Servaes and Zenner, 1996).

Overall, the explanatory power of all our models is relatively low, since the Adjusted $\mathrm{R}^{2}$ ranges from $0 \%$ to $9.8 \%$. Nonetheless, this finding is typically observed in regressions of bidder CARs (Fuller et al. 2002; DeLong 2003; Moeller et al., 2004).

\section{Insert Table 8 here}

\subsection{Bidder fixed effects}

It is possible that the difference in market reaction between listed and unlisted bids does not relate to the target firm's listing status. It is also possible that there could be a firmspecific driver of acquisition success that can explain the variation in bidder abnormal

\footnotetext{
${ }^{14}$ We also used the natural logarithm of the bidding firm's market value of equity 5 days before the merger announcement, as an alternative specification for Bidder Size. Results remained unchanged.
} 
returns. In other words, firms that were good past acquirers are likely to engage in value-enhancing acquisitions in the future, and vice versa. In this case, the persistency of the acquirer returns may account for the positive market reaction in specific merger announcements. It is also likely, that the listing effect is due to the differences in the characteristics between bidders of public and private targets, and does not relate to the type of the target.

To control for these possibilities, Fuller et al. (2002) utilize a sample where the same bidders make different types of acquisitions. In particular, their sample consists of firms that made at least five successful acquisitions within a three-year period (both public and nonpublic). This research design enables the direct examination of the differences in announcement period returns for bidders of both public and private targets. Their results confirm the existence of a listing effect for firms that acquire targets of different listing status, in non-financial U.S. mergers. In our study however, we focus primarily on financial firms. This means that if we apply the criteria of Fuller et al. (2002), the number of usable observations will be dramatically decreased. Hence, in the spirit of Golubov et al. (2015), we include bidder fixed effects in the baseline regressions of Table 8 , to test whether our results are determined by the listing status of the target firm, or the bidding firm itself. ${ }^{15}$ With this approach, we examine whether there is an unobserved, time-invariant, bidder-specific factor that can better explain the difference in market reaction between listed and unlisted bids. In our fixed effects regressions we include dummy variables to account for the different types of the target (Private, Subsidiary) as well as interactions terms between Private and Subsidiary dummies, with the Advisors and Top-Tier dummies, respectively. To ensure the robustness of our

\footnotetext{
${ }^{15}$ In this case, we do not partition the sample based on the target firm's listing status, since the same bidder could have acquired both private and public targets.
} 
aforementioned results, we expected the coefficients for the privately-held targets to be positive and statistical significant. As before, the dependent variable in all our regression is the five-day bidder CAR, centered on the announcement date.

Table 9 illustrates the results of our fixed effects regressions. The coefficients of Combo, RelSize, Volatility, Pooling, FIRREA, GLBA, and DFA are similar to what we have found in the OLS regressions. Strikingly, our results indicate, that there is indeed a firm-specific factor that drives bidder abnormal returns. In all our models, bidder fixed effects are highly significant (at 1\% level), leading us to reject the null hypothesis of insignificant joint effects. These findings imply that bidder returns are persistent overtime: good acquirers continue to create shareholder wealth value through M\&As, while bad acquirers continue to perform poorly. Furthermore, in line with Golubov et al. (2015), the inclusion of the bidder fixed effects almost doubles the explanatory power of our regression models, since the Adjusted $\mathrm{R}^{2}$ ranges from $17.2 \%$ to $17.4 \%$. However, what it is important to us is that the coefficients of Private and Private*Advisors are also positive and significant. The magnitude of their coefficients is comparable, albeit smaller, with the regression results reported in Table 8. These findings suggest that when bidding banks buy privately-held targets, and particularly when they employ a financial advisor for the transaction, they experience larger abnormal returns relative to their peers, even after controlling for any time-invariant bidder characteristics.

\section{Insert Table 9 here}

\subsection{Control for sample selection}


Our analysis so far is based on the assumption that the choice of target firm is exogenously determined. However, it is likely that the acquirers of private targets in our sample were not selected randomly from the population of U.S. banking firms, suggesting that the type of the target firm may be determined endogenously. In this case, the choice of a target firm may be correlated with certain bidder and/or dealspecific characteristics, and the OLS estimates become unreliable. To address this sample selection issue, we employ Heckman's (1979) two-stage procedure, using the inverse Mills ratio.

As in Doukas et al. (2014), the first-stage equation of the Heckman's procedure is estimated by a probit regression, where the dependent variable is one for acquirers of private targets and zero for acquirers of public targets. From this stage we construct the inverse Mills ratio that we add as an additional independent variable in the second-stage equation. Next, the second-stage equation is an OLS regression where the dependent variable is bidder CARs for private deals only. The coefficients we obtain from this regression are corrected for the sample selection bias.

Table 10 presents the results for this analysis. We conduct the Henchman's procedure three times, to obtain comparable results with the ones reported in Table 8. According to our probit models, the choice of private target is negatively related to geographical focus, any form of stock financing, relative size of the deal, bidder size, and the use of an advisor on the part of the bidder. The Pseudo $\mathrm{R}^{2}$ of these first-stage equations indicate that our probit models explain up to $29.7 \%$ of the choice between a public and a private target. More importantly, the results from the OLS regression in the secondstage equations are almost identical with the results in Table 10. In private offers, bidder CARs increase with the use of a financial advisor, after controlling for sample selection. 
In fact, the Inverse Mills ratio is insignificant in all three cases, suggesting that the selection bias should not be a primary concern in our regression analysis. ${ }^{16}$

\section{$\underline{\text { Insert Table } 10 \text { here }}$}

\section{Conclusion}

In this paper, we examine bidder abnormal returns in 2,178 successful M\&As of publicly traded U.S. banking companies announced between 1984 and 2015, as well as the differences in stock market reaction for separate types of targets. Initially, our findings indicate the presence of a listing effect in acquisitions by U.S. banks: Cumulative abnormal returns for unlisted bids (privately-held companies and subsidiaries), are significantly larger than for listed bids. In fact, these results are in line with prior literature in non-financial U.S M\&As.

The intriguing part of this analysis however, is to find an explanation for this phenomenon. Much of the existing literature in the non-financial mergers attributes the different market reaction between listed and unlisted bids to method of payment effects. In particular, these explanations predict larger bidder CARs in private offers, when the deal is financed with common stock. Equity offers could help resolving financial asymmetries in the target firm's valuation, or result in the creation of effective performance monitors in the bidding firm. Nonetheless, in our sample, we don't find any empirical support for method of payment effects in private offers. On the contrary, bidding banks gain in such transactions, even when they pay with cash, stock, or a combination of the two. Moreover, we find that our results are not due to potential

\footnotetext{
${ }^{16} \mathrm{We}$ repeated the same procedure for the choice between listed and unlisted targets. The results were qualitatively similar.
} 
leakages of information about public acquisitions or limited competition for private targets. We further account for the several legislative changes in the U.S. banking industry. Notably, the listing effect is pervasive across all regulatory reforms.

We examine the role of the financial advisors in the acquisitions by U.S. banks, and if the use of a financial advisor from the bidding banks has any predictive power in explaining announcement abnormal returns. Presumably, financial advisory services should be of major importance in reducing valuation uncertainties for acquirers of privately-held financial firms. Similarly, we predict positive abnormal returns for bidding banks that use financial advisors in private offers. Our results document that in-house acquisitions of private firms yield negative bidder returns in the scale of $0.59 \%$, whereas when an advisor is used, bidder abnormal returns are $1.47 \%$, and statistical significant at $1 \%$. This substantial difference in market reaction suggests that the acquisition of privately-held financial firm results in a positive market reaction only when a financial advisor is used on the part of the bidding bank. Otherwise, the bidder abnormal returns for private bids are similar to the ones reported for public bids. Lastly, results for subsidiary targets are inconclusive, and financial advisor reputation has a negative effect in bidder CARs in all cases.

In cross-sectional regressions, where the five-day abnormal returns are the dependent variable, the listing effect is robust to the inclusion of several frequently-used independent variables such as bidder size, method of payment, geographical scope, and prior bidder performance. More precisely, our indicator variables that proxy for the listing status of the target firm and the use of bidder financial advisors in private offers are positive and statistical significant in all regressions. To account for the possibility that a bidder-specific factor may better explain the variation in bidder CARs, we included bidder fixed effects in our regressions. Despite the presence of a strong bidder 
fixed effect in our sample, banks that acquire privately-held financial firms and use non-top-tier financial advisors in their transactions, experience larger abnormal returns relative to their competitors. Lastly, we control for the endogenous nature of biddertarget matching. This analysis suggests that sample selection does not influence the consistency of our OLS estimates. 


\section{References}

Arikan, A.M., Stulz, R.M., 2016. Corporate acquisitions, diversification, and the firm's life cycle. The Journal of Finance 71, 139-194.

Barnes, B.G., Harp, N.L., Oler, D., 2014. Evaluating the SDC mergers and acquisitions database. Financial Review 49, 793-822.

Becher, D.A., 2000. The valuation effects of bank mergers. Journal of Corporate Finance 6, 189-214.

Becher, D.A., 2009. Bidder returns and merger anticipation: Evidence from banking deregulation. Journal of Corporate Finance 15, 85-98.

Becher, D.A., Campbell, T.L., 2005. Interstate banking deregulation and the changing nature of bank mergers. Journal of Financial Research 28, 1-20

Boehmer, E., Masumeci, J., Poulsen, A.B., 1991. Event-study methodology under conditions of event-induced variance. Journal of Financial Economics 30, 253-272.

Bowers, H.M., Miller, R.E., 1990. Choice of investment banker and shareholders' wealth of firms involved in acquisitions. Financial Management, 34-44.

Brander, J.A., Egan, E.J., 2017. The winner's curse in acquisitions of privately-held firms. The Quarterly Review of Economics and Finance, Forthcoming.

Brewer, E., Jagtiani, J., 2013. How much did banks pay to become too-big-to-fail and to become systemically important? Journal of Financial Services Research 43, 1-35.

Brown, J.S., Warner, J.B., 1985. Using daily stock returns: The case of event studies, Journal of Financial Economics 14, 3-31.

Carow, K.A., Heron, R.A., 1998. The interstate banking and branching efficiency act of 1994: A wealth event for acquisition targets. Journal of Banking and Finance 22, 175-196.

Chang, S., 1998. Takeovers of privately held targets, methods of payment, and bidder returns. Journal of Finance 53, 773-784.

Cornett, M.M., De, S., 1991. Common stock returns in corporate takeover bids: Evidence from interstate bank mergers. Journal of Banking and Finance 15, 273-295.

DeLong, G.L., 2001. Stockholder gains from focusing versus diversifying bank mergers. Journal of Financial Economics 59, 221-252.

DeLong, G.L., 2003. The announcement effects of U.S. versus non-U.S. bank mergers: Do they differ? Journal of Financial Research 26, 487-500.

DeLong, G.L., DeYoung, R., 2007. Learning by observing: Information spillovers in the execution and valuation of commercial bank M\&As. Journal of Finance 62, 181 216. 
Desai, A.S., Stover, R.D., 1985. Bank holding company acquisitions, stockholder returns, and regulatory uncertainty. Journal of Financial Research 8, 145-156.

Doukas, J., Gonenc, H., Plantinga, A., 2014. Private acquisition gains: A contingent claims explanation. The European Journal of Finance, 20, 1090-1113.

Faccio, M., McConnell, J. J., Stolin, D., 2006. Returns to acquirers of listed and unlisted targets. Journal of Financial and Quantitative Analysis 41, 197-220

Fama, E.F., French, K.R., 1997. Industry costs of equity. Journal of Financial Economics 43, 153-193.

Fang, L.H., 2005. Investment bank reputation and the price and quality of underwriting services, Journal of Finance 60, 2729-2761.

Filson, D., Olfati, S., 2014. The impacts of Gramm-Leach-Bliley bank diversification on value and risk. Journal of Banking and Finance 41, 209-221

Fuller, K., Netter, J., Stegemoller, M., 2002. What do returns to acquiring firms tell us? Evidence from firms that make many acquisitions. Journal of Finance 57, 1763-1793.

Golubov, A., Petmezas, D., Travlos, N.G., 2012. When it pays to pay your investment banker: New evidence on the role of financial advisors in M\&As. The Journal of Finance 67, 271-311.

Golubov, A., Yawson, A., Zhang, H., 2015. Extraordinary acquirers. Journal of Financial Economics, 116, 314-330.

Graham, M., Walter, T.S., Yawson, A., Zhang, H., 2017. The value-added role of industry specialist advisors in M\&As. Journal of Banking \& Finance, 81, 81-104.

Gupta, A., Misra, L., 2007. Deal size, bid premium, and gains in bank mergers: The impact of managerial motivations. Financial Review 42, 373-400.

Hagendorff, J., Vallascas, F., 2011. CEO pay incentives and risk-taking: Evidence from bank acquisitions. Journal of Corporate Finance 17, 1078-1095.

Hansen, R.G., 1987. A theory for the choice of exchange medium in mergers and acquisitions. Journal of Business 60, 75-95.

Heckman, J.J., 1979. Sample selection bias as a specification error. Econometrica 47, $153-161$.

Houston, J.F., Ryngaert, M.D., 1994. The overall gains from large bank mergers. Journal of Banking and Finance 18, 1155-1176.

Houston, J.F., Ryngaert, M.D., 1997. Equity issuance and adverse selection: A direct test using conditional stock offers. Journal of Finance 52, 197-219.

Hunter, W.C., Jagtiani, J., 2003. An analysis of advisor choice, fees, and effort in 
mergers and acquisitions. Review of Financial Economics 12, 65-81.

Ismail, A., 2010. Are good financial advisors really good? The performance of investment banks in the M\&A market. Review of Quantitative Finance and Accounting, 35, 411-429.

James, C.M., Wier, P., 1987. Returns to acquirers and competition in the acquisition market: The case of banking. Journal of Political Economy 95, 355-370.

Jensen, M.C., Ruback, R.S. 1983. The market for corporate control: The scientific evidence. Journal of Financial Economics, 11, 5-50.

John, K., Freund, S., Nguyen, D., Vasudevan, G.K., 2010. Investor protection and cross-border acquisitions of private and public targets. Journal of Corporate Finance $16,259-275$.

Kwan, S.H., Carleton, W.T., 2010. Financial contracting and the choice between private placement and publicly offered bonds. Journal of Money, Credit and Banking 42, $907-$ 929.

Leledakis, G.N., Pyrgiotakis, E.G., 2016. U.S. Bank M\&A's in the post Dodd Frank Act era: Do they create value? Available at SSRN: https://ssrn.com/abstract=2828652.

Martin, K.J., 1996. The method of payment in corporate acquisitions, investment opportunities, and management ownership, Journal of Finance 51, 1227-1246.

McLaughlin, R.M., 1992. Does the form of compensation matter?: Investment banker fee contracts in tender offers. Journal of Financial Economics 32, 223-260.

Mitchell, M.L., Mulherin, J.H., 1996. The impact of industry shocks on takeover and restructuring activity. Journal of Financial Economics 41, 193-229.

Moeller, S. B., Schlingemann, F. P., Stulz, R. M., 2007. How do diversity of opinion and information asymmetry affect acquirer returns? Review of Financial Studies 20,2047-2078

Moeller, S.B., Schlingemann, F.P., Stulz, R.M., 2004. Firm size and the gains from acquisitions. Journal of Financial Economics 73, 201-228.

Officer, M.S., Poulsen, A.B., Stegemoller, M., 2009. Target-firm information asymmetry and acquirer returns. Review of Finance 13, 467-493

Rau, P.R., 2000. Investment bank market share, contingent fee payments, and the performance of acquiring firms. Journal of Financial Economics 56, 293-324.

Schipper, K., Thompson, R., 1983. Evidence on the capitalized value of merger activity for acquiring firms. Journal of Financial Economics 11, 85-119.

Servaes, H., Zenner, M., 1996. The role of investment banks in acquisition. Review of Financial Studies 9, 787-815. 
Travlos, N.G., 1987. Corporate takeover bids, methods of payment, and bidding firms' stock returns. Journal of Finance 42, 943-963.

Wagner, W., 2007. Financial development and the opacity of banks. Economics Letters 97, 6-10.

White, H., 1980. A heteroskedasticity-consistent covariance matrix estimator and a direct test for heteroskedasticity. Econometrica 48, 817-838. 


\section{Appendix: Variable definitions}

\begin{tabular}{|c|c|}
\hline \multicolumn{2}{|r|}{ Panel A: Deal Characteristics } \\
\hline Variables & Definition \\
\hline State & $\begin{array}{l}\text { Dummy variable: } 1 \text { if both bidder and target are headquartered in the same } \\
\text { state, and } 0 \text { otherwise. }\end{array}$ \\
\hline Stock & $\begin{array}{l}\text { Dummy variable: } 1 \text { when the deal is finances purely with stock, and } 0 \\
\text { otherwise. }\end{array}$ \\
\hline Combo & $\begin{array}{l}\text { Dummy variable: } 1 \text { if the deal was financed with a combination of cash and } \\
\text { stock, and } 0 \text { otherwise. }\end{array}$ \\
\hline RelSize & $\begin{array}{l}\text { The transaction value divided by the equity market capitalization of the } \\
\text { bidding company } 5 \text { days prior to the merger announcement }\end{array}$ \\
\hline Private & $\begin{array}{l}\text { Dummy variable: } 1 \text { for acquisitions of privately-held targets, and } 0 \\
\text { otherwise. }\end{array}$ \\
\hline Subsidiary & Dummy variable: 1 for acquisitions of subsidiary targets, and 0 otherwise. \\
\hline Pooling & $\begin{array}{l}\text { Dummy variable: } 1 \text { if the bidder had used the pooling accounting method to } \\
\text { incorporate the target into its books, and } 0 \text { otherwise. }\end{array}$ \\
\hline \multicolumn{2}{|r|}{ Panel B: Bidder Characteristics } \\
\hline Variables & Definition \\
\hline Bidder Size & $\begin{array}{l}\text { The natural logarithm of the bidding firm's total assets at year-end prior to } \\
\text { the merger announcement. }\end{array}$ \\
\hline Volatility & $\begin{array}{l}\text { The standard deviation of the market-adjusted residuals from } 210 \text { to } 20 \text { days } \\
\text { prior to the merger announcement. }\end{array}$ \\
\hline ROA & $\begin{array}{l}\text { Bidding firms' return on assets (ROA) at year-end prior to the merger } \\
\text { announcement }\end{array}$ \\
\hline \multicolumn{2}{|r|}{ Panel C: Financial Advisor } \\
\hline Variables & Definition \\
\hline Advisors & $\begin{array}{l}\text { Dummy variable: } 1 \text { if the bidding firms had employed at least one financial } \\
\text { advisor, and } 0 \text { otherwise. }\end{array}$ \\
\hline Top-Tier & $\begin{array}{l}\text { Dummy variable: } 1 \text { for financial advisors that belong to the top-tier group, } \\
\text { or } 0 \text { otherwise. }\end{array}$ \\
\hline \multicolumn{2}{|r|}{ Panel D: Regulatory periods } \\
\hline Variables & Definition \\
\hline FIRREA & $\begin{array}{l}\text { Dummy variable: } 1 \text { for deals announced during the FIRREA period (October } \\
1989 \text { to June 1997), and } 0 \text { otherwise. }\end{array}$ \\
\hline Riegle-Neal & $\begin{array}{l}\text { Dummy variable: } 1 \text { for deals announced during the Riegle-Neal period (July } \\
1997 \text { to March 2000), and } 0 \text { otherwise. }\end{array}$ \\
\hline GLBA & $\begin{array}{l}\text { Dummy variable: } 1 \text { for deals announced during the Gramm-Leach-Bliley } \\
\text { period (April } 2000 \text { to June 2010), and } 0 \text { otherwise. }\end{array}$ \\
\hline DFA & $\begin{array}{l}\text { Dummy variable: } 1 \text { for deals announced during the Dodd-Frank period (July } \\
2010 \text { to December 2015), and } 0 \text { otherwise. }\end{array}$ \\
\hline
\end{tabular}




\section{Table 1}

Merger size by announcement year and target firm's listing status.

This table contains means for the total value of consideration paid by the bidder, excluding fees and expenses, segmented by year and target firm's listing status. All values are adjusted for inflation (in 2015 million \$). The sample consists of all successful M\&As by U.S. banking firms, with initial bids announced between January 1, 1984 and December 31, 2015. Bidders are commercial banks with a threedigit primary SIC code equal to 602, or bank holding companies with a four-digit primary SIC code equal to 6712. Targets are comprised of publicly traded, privately-held firms, and unlisted subsidiaries of publicly traded firms. Merger data are collected from Thomson ONE database.

\begin{tabular}{|c|c|c|c|c|c|c|c|c|}
\hline \multirow[b]{2}{*}{ Year } & \multicolumn{2}{|l|}{ All } & \multicolumn{2}{|c|}{ Public } & \multicolumn{2}{|c|}{ Private } & \multicolumn{2}{|c|}{ Subsidiary } \\
\hline & Mean & $\mathrm{N}$ & Mean & $\mathrm{N}$ & Mean & $\mathrm{N}$ & Mean & $\mathrm{N}$ \\
\hline 1984 & 88.307 & 28 & 429.613 & 3 & 47.851 & 24 & 35.34 & 1 \\
\hline 1985 & 352.382 & 20 & 756.003 & 8 & 90.589 & 10 & 46.86 & 2 \\
\hline 1986 & 314.209 & 44 & 990.255 & 10 & 92.047 & 31 & 356.4 & 3 \\
\hline 1987 & 380.896 & 52 & $1,067.29$ & 16 & 64.141 & 33 & 204.437 & 3 \\
\hline 1988 & 188.433 & 24 & 529.703 & 6 & 61.128 & 17 & 305 & 1 \\
\hline 1989 & 222.874 & 55 & 549.955 & 18 & 39.801 & 32 & 217.052 & 5 \\
\hline 1990 & 143.769 & 35 & 64.556 & 8 & 74.228 & 23 & 702.054 & 4 \\
\hline 1991 & 580.61 & 56 & $1,219.65$ & 25 & 38.74 & 23 & 141.477 & 8 \\
\hline 1992 & 256.583 & 70 & 437.778 & 32 & 97.507 & 33 & 146.834 & 5 \\
\hline 1993 & 176.325 & 133 & 420.435 & 42 & 54.932 & 77 & 111.655 & 14 \\
\hline 1994 & 142.474 & 162 & 330.703 & 50 & 53.985 & 99 & 92.399 & 13 \\
\hline 1995 & 628.09 & 122 & $1,486.20$ & 50 & 29.615 & 63 & 50.152 & 9 \\
\hline 1996 & 294.718 & 105 & 714.209 & 34 & 58.584 & 66 & 559.153 & 5 \\
\hline 1997 & 911.925 & 153 & $2,525.90$ & 48 & 83.744 & 90 & 716.303 & 15 \\
\hline 1998 & $1,316.581$ & 144 & $3,892.70$ & 46 & 76.029 & 88 & 383.322 & 10 \\
\hline 1999 & 517.509 & 101 & $1,057.70$ & 45 & 56.727 & 48 & 243.606 & 8 \\
\hline 2000 & $1,083.804$ & 75 & $1,972.67$ & 38 & 47.626 & 32 & 959.932 & 5 \\
\hline 2001 & 405.048 & 75 & 872.118 & 28 & 56.25 & 41 & 608.833 & 6 \\
\hline 2002 & 329.798 & 48 & 612.72 & 17 & 39.503 & 25 & 737.744 & 6 \\
\hline 2003 & 1070.27 & 87 & $2,279.31$ & 35 & 54.819 & 43 & $1,220.05$ & 9 \\
\hline 2004 & $1,353.785$ & 100 & $3,092.06$ & 42 & 64.876 & 48 & 239.814 & 10 \\
\hline 2005 & 800.856 & 85 & $2,643.28$ & 22 & 146.115 & 61 & 503.807 & 2 \\
\hline 2006 & $1,254.437$ & 71 & $3,390.29$ & 23 & 70.395 & 44 & $1,997.73$ & 4 \\
\hline 2007 & 378.862 & 62 & 746.984 & 27 & 90.926 & 32 & 137.086 & 3 \\
\hline 2008 & $3,674.209$ & 23 & $5,225.92$ & 16 & 127.439 & 7 & 0 & 0 \\
\hline 2009 & 213.396 & 11 & 113.747 & 5 & 10.936 & 3 & 581.937 & 3 \\
\hline 2010 & 393.381 & 20 & 403.162 & 12 & 18.59 & 4 & 738.829 & 4 \\
\hline 2011 & 105.434 & 20 & 170.743 & 8 & 35.319 & 10 & 194.775 & 2 \\
\hline 2012 & 252.622 & 31 & 419.317 & 16 & 74.815 & 15 & 0 & 0 \\
\hline 2013 & 206.434 & 46 & 339.411 & 18 & 103.108 & 25 & 269.62 & 3 \\
\hline 2014 & 140.399 & 62 & 254.808 & 24 & 64.39 & 37 & 206.9 & 1 \\
\hline 2015 & 285.285 & 58 & 602.002 & 18 & 63.555 & 35 & 697.217 & 5 \\
\hline Total & 609.250 & 2,178 & $1,479.740$ & 790 & 67.497 & 1,219 & 447.776 & 169 \\
\hline
\end{tabular}




\section{Table 2}

\section{Merger Activity by target firm's}

This table reports, by industry of the target firm, the fraction of sample firms that were acquired from 1984 to 2015. Bidders are commercial banks with a three-digit primary SIC code equal to 602, or bank holding companies with a four-digit primary SIC code equal to 6712. Targets are comprised of publicity traded, privately-held firms, and unlisted subsidiaries of publicity traded firms. Target industry data are organized following Fama and French (1997) 48-industry classifications, using four-digit Primary SIC codes. Merger data are obtained from Thomson ONE database.

\begin{tabular}{lrrrr}
\hline Target Industry & All & Public & Private & Subsidiary \\
\hline Machinery & 1 & 0 & 1 & 0 \\
Personal Services & 1 & 1 & 0 & 0 \\
Business Services & 27 & 5 & 15 & 7 \\
Retail & 1 & 0 & 0 & 1 \\
Banking & 1,947 & 730 & 1,078 & 139 \\
Insurance & 18 & 0 & 17 & 1 \\
Real Estate & 3 & 0 & 2 & 1 \\
Trading & 180 & 54 & 106 & 20 \\
\hline Total & 2,178 & 790 & 1,219 & 169 \\
\hline
\end{tabular}




\section{Table 3}

Summary statistics by target firm's listing status.

This table summarizes descriptive statistics for all M\&As of our sample, segmented by the target firm's listing status. The sample consists of all successful M\&As by U.S. banking firms, with initial bids announced between January 1, 1984 and December 31,2015. Bidders are commercial banks with a threedigit primary SIC code equal to 602, or bank holding companies with a four-digit primary SIC code equal to 6712. Targets are comprised of publicly traded, privately-held firms, and unlisted subsidiaries of publicly traded firms. Panel A displays statistics for deal-specific variables. The transaction value is the total value of consideration paid by the bidder, excluding fees and expenses (in 2015 million \$). Days to completion measures the calendar days between the announcement and effective dates. The percentages of cash, stock, and combo deals represent the method of payment. Geographic diversification is measured by the percentage of same state deals. The percentage of pooling method denotes the mergers that use the pooling method versus the purchase method to incorporate the target into the bidding firm's books. The percentage of single bidders denotes the percentage of deals where the target firm received only one bid. Target's equity percentages acquired and owned represent the proportion of target's equity the bidder acquired in the transaction and owned after the transaction, respectively. Panel B details statistics for bidder-specific variables. Total Assets are the bidding firm's total assets at year-end prior to the merger announcement (in 2015 million \$). Market Value is the bidding firm's market capitalization at year-end prior to the merger announcement (in 2015 million \$). ROA is the bidding firm's return on assets at yearend prior to the merger announcement. Median values are in brackets.

\begin{tabular}{lrrrr}
\hline & All & Public & Private & Subsidiary \\
\hline Panel A: Deal characteristics & & & & \\
\hline Transaction value (million \$) & 609.25 & $1,479.74$ & 67.50 & 447.78 \\
& {$[60.72]$} & {$[203.71]$} & {$[32.56]$} & {$[86.92]$} \\
Days to completion & 170.79 & 191.84 & 162.79 & 130.08 \\
& {$[161.00]$} & {$[175.00]$} & {$[151.00]$} & {$[123.00]$} \\
\% of cash deals & 25.67 & 11.39 & 27.73 & 77.51 \\
\% of stock deals & 48.53 & 59.11 & 47.17 & 8.88 \\
\% of combo deals & 25.80 & 29.50 & 25.10 & 13.61 \\
\% same state deals & 48.53 & 45.44 & 52.09 & 37.28 \\
\% pooling method & 21.63 & 27.97 & 20.26 & 1.78 \\
\% single bidders & 98.86 & 98.10 & 99.92 & 100 \\
\% Target's equity acquired in transaction & 99.66 & 99.66 & 99.64 & 99.79 \\
\% Target's equity owned after transaction & 99.79 & 99.85 & 99.74 & 99.79 \\
\hline Panel B: Bidder characteristics & & & & \\
\hline Total assets (million \$) & $46,137.81$ & $57,244.15$ & $18,578.80$ & $192,939.30$ \\
& {$[7,515.37]$} & {$[13,450.43]$} & {$[4,634.35]$} & {$[27,918.38]$} \\
Market value of equity (million \$) & $7,3668.55$ & $9,965.42$ & $2,853.78$ & $27,794.48$ \\
& {$[1,091.23]$} & {$[2,129]$} & {$[707.07]$} & {$[3,387.48]$} \\
ROA & 1.05 & 1.04 & 1.07 & 0.99 \\
& {$[1.04]$} & {$[1.06]$} & {$[1.04]$} & {$[1.00]$} \\
\hline
\end{tabular}


Table 4

Top-25 financial advisors ranked by transaction value

The table illustrates the top-25 financial advisor rankings over the period 2984 to 2015 . The financial advisors are ranked based on the transaction value of deals they advised for a sample of M\&As targeting U.S. firms. Transaction value is the total consideration paid for the target minus any liabilities assumed in transaction plus the target firm's net debt (in \$ millions). Credit is allocated to surviving/parent firms and to each eligible advisor in case of multiple advisors for a single entity. We exclude equity carve-outs, exchange offers, and open market repurchases.

\begin{tabular}{|c|c|c|c|c|c|c|c|}
\hline \multicolumn{4}{|c|}{ Announced Transactions } & \multicolumn{4}{|c|}{ Completed Transactions } \\
\hline Rank & Financial Advisor & Transaction Value & Number of Deals & Rank & Financial Advisor & Transaction Value & Number of Deals \\
\hline \multicolumn{8}{|c|}{ Top-Tier Financial Advisors } \\
\hline 1 & Goldman Sachs \& Co & $9,171,621.71$ & 5,170 & 1 & Goldman Sachs \& Co & $8,696,073.32$ & 5,046 \\
\hline 2 & Morgan Stanley & $7,056,243.57$ & 4,226 & 2 & Morgan Stanley & $6,595,234.87$ & 4,163 \\
\hline 3 & Bank of America Merrill Lynch & $6,681,615.86$ & 5,499 & 3 & Bank of America Merrill Lynch & $6,316,775.23$ & 5,387 \\
\hline 4 & JP Morgan & $6,520,060.41$ & 4,908 & 4 & JP Morgan & $6,211,820.40$ & 4,818 \\
\hline 5 & Citi & $5,419,015.57$ & 4,782 & 5 & Citi & $5,061,962.47$ & 4,714 \\
\hline 6 & Credit Suisse & $4,937,269.24$ & 5,364 & 6 & Credit Suisse & $4,589,817.29$ & 5,305 \\
\hline 7 & Barclays & $4,384,337.67$ & 3,295 & 7 & Barclays & $4,082,195.80$ & 3,254 \\
\hline 8 & Lazard & $2,814,979.35$ & 2,252 & 8 & Lazard & $2,572,256.75$ & 2,191 \\
\hline \multicolumn{8}{|c|}{ Non-Top-Tier Financial Advisors } \\
\hline 9 & UBS & $2,623,536.10$ & 3,265 & 9 & UBS & $2,438,392.08$ & 3,252 \\
\hline 10 & Deutsche Bank & $2,183,201.29$ & 2,386 & 10 & Deutsche Bank & $1,995,843.37$ & 2,357 \\
\hline 11 & Evercore Partners & $1,511,295.59$ & 643 & 11 & Evercore Partners & $1,264,683.56$ & 599 \\
\hline 12 & Centerview Partners LLC & $867,383.97$ & 178 & 12 & Commerzbank AG & $726,901.29$ & 543 \\
\hline 13 & Commerzbank AG & $727,171.74$ & 552 & 13 & Wells Fargo \& Co & $697,188.30$ & 1,152 \\
\hline 14 & Wells Fargo \& Co & $713,205.85$ & 1,181 & 14 & PJT Partners Inc & $652,395.47$ & 443 \\
\hline 15 & PJT Partners Inc & $681,484.22$ & 467 & 15 & Centerview Partners LLC & $649,428.79$ & 152 \\
\hline 16 & Houlihan Lokey & $642,340.07$ & 2,686 & 16 & Houlihan Lokey & $637,600.67$ & 2,578 \\
\hline 17 & Jefferies LLC & $607,868.26$ & 1,981 & 17 & Jefferies LLC & $594,458.62$ & 1,940 \\
\hline 18 & Greenhill \& Co, LLC & $527,069.08$ & 270 & 18 & Greenhill \& Co, LLC & $469,317.48$ & 252 \\
\hline 19 & RBC Capital Markets & $494,477.80$ & 1,713 & 19 & Rothschild \& Co & $443,360.89$ & 544 \\
\hline 20 & Rothschild \& Co & $483,153.12$ & 562 & 20 & Stifel/KBW & $417,217.82$ & 1,769 \\
\hline 21 & Moelis \& Co & $437,554.50$ & 498 & 21 & RBC Capital Markets & $413,838.82$ & 1,672 \\
\hline 22 & Stifel/KBW & $423,166.65$ & 1,818 & 22 & Moelis \& Co & $340,036.21$ & 465 \\
\hline 23 & Allen \& Co Inc & $403,219.73$ & 187 & 23 & Allen \& Co Inc & $318,107.71$ & 184 \\
\hline 24 & Guggenheim Securities LLC & $373,673.24$ & 88 & 24 & BNP Paribas SA & $241,047.45$ & 103 \\
\hline 25 & BNP Paribas SA & $272,742.58$ & 107 & 25 & Guggenheim Securities LLC & $237,546.10$ & 80 \\
\hline
\end{tabular}




\section{Table 5}

Bidder cumulative abnormal returns around the announcement date

This table illustrates the bidder announcement cumulative abnormal returns. The sample consists of all successful M\&As by U.S. banking firms, with initial bids announced between January 1, 1984 and December 31, 2015. Bidders are commercial banks with a three-digit primary SIC code equal to 602, or bank holding companies with a four-digit primary SIC code equal to 6712. Targets are comprised of publicly traded, privately-held firms, and unlisted subsidiaries of publicly traded firms. Abnormal returns are estimated using the market adjusted returns model for a five-day event window centered on the announcement date $(-2,+2)$. Results are further segmented according to the method of payment. Cash financing includes combination of cash, debt, and liabilities. Stock financing includes payments with common stock and combinations of commons stock, warrants, or options. Combo financing includes combination of cash, common stock, debt, preferred stock, convertible securities, and methods classified as "other consideration" by Thomson ONE database. The median CARs are in brackets and the number of mergers is below the medians. The parametric test is the standardized cross-sectional test, and the nonparametric is the Wilcoxon signed rank test. The symbols $*, * *$, and $* * *$ denote statistical significance at the $0.10,0.05$ and 0.01 levels respectively, using a 2-tail test.

\begin{tabular}{lcccc}
\hline & All & Public & Private & Subsidiary \\
\hline All bids & $-0.18 \% \%^{* *}$ & $-1.45 \% \%^{* *}$ & $0.58 \% \%^{* *}$ & $0.31 \%$ \\
& {$[-0.36 \%]^{* * *}$} & {$[-1.34 \%]^{* * *}$} & {$[0.21 \%]^{* * *}$} & {$[-0.32 \%]$} \\
& 2,178 & 790 & 1,219 & 169 \\
Cash & $0.43 \%$ & $-0.18 \%$ & $0.61 \%{ }^{* *}$ & $0.41 \%$ \\
& {$[0.11 \%]$} & {$[0.12 \%]$} & {$[0.27 \%]^{* *}$} & {$[-0.31 \%]$} \\
& 559 & 90 & 338 & 131 \\
Stock & $-0.43 \% \%^{* *}$ & $-1.61 \% 0^{* *}$ & $0.56 \% * *$ & $-1.42 \%$ \\
& {$[-0.51 \%]^{* *}$} & {$[-1.37 \%]^{* * *}$} & {$[0.05 \%]$} & {$[0.21 \%]$} \\
& 1,057 & 467 & 575 & 15 \\
Combo & $-0.33 \% * * *$ & $-1.63 \% 0^{* * *}$ & $0.57 \% * *$ & $0.92 \%$ \\
& {$[-0.46 \%]^{* *}$} & {$[-1.64 \%]^{* * *}$} & {$[0.29 \%]^{*}$} & {$[-0.58 \%]$} \\
& 562 & 233 & 306 & 23 \\
\hline
\end{tabular}




\section{Table 6}

Bidder cumulative abnormal returns by regulatory period

This table illustrates the bidder announcement cumulative abnormal returns for each regulatory period. The sample consists of all successful M\&As by U.S. banking firms, with initial bids announced between January 1, 1984 and December 31, 2015. Bidders are commercial banks with a three-digit primary SIC code equal to 602, or bank holding companies with a four-digit primary SIC code equal to 6712. Targets are comprised of publicly traded, privately-held firms, and unlisted subsidiaries of publicly traded firms. Results are segmented based on the different regulatory periods. FIRREA refers to the Financial Institutions Reform, Recovery and Enforcement Act of 1989. Riegle-Neal is the Riegle-Neal Interstate Branching and Efficiency Act of 1994. GLBA refers to the Gramm-Leach-Bliley Financial Modernization Act of 1999. DFA refers to the Dodd-Frank Wall Street Reform and Consumer Protection Act of 2010. Regulatory periods are classified according to the dates when provisions of each piece of legislation became effective. Abnormal returns are estimated using the market adjusted returns model for a five-day event window centered on the announcement date $(-2,+2)$. The median CARs are in brackets and the number of mergers is below the medians. The parametric test is the standardized crosssectional test, and the non-parametric is the Wilcoxon signed rank test. Significance for the difference between mean CARs is based on the $t$-test. Significance for the difference between median CARs is based on the Mann-Whitney test (in brackets). The symbols ***, and *** denote statistical significance at the $0.10,0.05$ and 0.01 levels respectively, using a 2 -tail test.

\begin{tabular}{|c|c|c|c|c|c|c|}
\hline & All & Public & Private & Subsidiary & $\begin{array}{c}\text { Difference } \\
\text { Private- } \\
\text { Public } \\
\end{array}$ & $\begin{array}{c}\text { Difference } \\
\text { Subsidiary- } \\
\text { Public }\end{array}$ \\
\hline Pre-FIRREA & $\begin{array}{c}-1.06 \% * * * \\
{[-0.69 \%]^{* * *}} \\
198\end{array}$ & $\begin{array}{c}-2.80 \% * * * \\
{[-2.71 \%] * * *} \\
52\end{array}$ & $\begin{array}{c}-0.46 \% \\
{[-0.36 \%]} \\
133\end{array}$ & $\begin{array}{c}-0.28 \% \\
{[1.01 \%]} \\
13\end{array}$ & $\begin{array}{c}2.33 \% * * * \\
{[2.35 \%]^{* * *}}\end{array}$ & $\begin{array}{c}2.52 \% * \\
{[3.72 \%]^{*}}\end{array}$ \\
\hline FIRREA & $\begin{array}{c}-0.16 \% * * \\
{[-0.19 \%]} \\
756\end{array}$ & $\begin{array}{c}-1.32 \% * * * \\
{[-1.26 \%]^{* * *}} \\
269\end{array}$ & $\begin{array}{c}0.56 \% * * * \\
{[0.50 \%]^{* * *}} \\
423\end{array}$ & $\begin{array}{c}-0.03 \% \\
{[-0.09 \%]} \\
64\end{array}$ & $\begin{array}{c}1.88 \% * * * \\
{[1.76 \%]^{* * *}}\end{array}$ & $\begin{array}{c}1.30 \% * * \\
{[1.17 \%]^{* *}}\end{array}$ \\
\hline Riegle-Neal & $\begin{array}{c}-0.84 \% * * * \\
{[-0.87 \%]^{* * *}} \\
359\end{array}$ & $\begin{array}{c}-2.83 \% * * * \\
{[-2.60 \%] * * *} \\
126\end{array}$ & $\begin{array}{c}0.30 \% \\
{[-0.31 \%]} \\
204\end{array}$ & $\begin{array}{c}-0.24 \% \\
{[-0.22 \%]} \\
29\end{array}$ & $\begin{array}{c}3.13 \% * * * \\
{[2.29 \%]^{* * *}}\end{array}$ & $\begin{array}{c}2.59 \% * * * \\
{[2.38 \%]^{* * *}}\end{array}$ \\
\hline GLBA & $\begin{array}{c}0.10 \% * * \\
{[-0.52 \%]^{*}} \\
635\end{array}$ & $\begin{array}{c}-1.00 \% * * * \\
{[-1.05 \%] * * *} \\
250\end{array}$ & $\begin{array}{c}0.76 \% \\
{[0.02 \%]} \\
335\end{array}$ & $\begin{array}{c}1.15 \% \\
{[-0.53 \%]} \\
50\end{array}$ & $\begin{array}{c}1.76 \% * * * \\
{[1.07 \%]^{* * *}}\end{array}$ & $\begin{array}{l}2.15 \% * * \\
{[0.52 \%]^{*}}\end{array}$ \\
\hline Dodd-Frank & $\begin{array}{c}0.79 \% * * * \\
{[0.50 \%]^{* *}} \\
230\end{array}$ & $\begin{array}{c}-0.41 \% \\
{[-0.44 \%]} \\
93\end{array}$ & $\begin{array}{c}1.71 \% * * * \\
{[1.23 \%]^{* * *}} \\
124\end{array}$ & $\begin{array}{c}0.61 \% \\
{[-0.64 \%]} \\
13\end{array}$ & $\begin{array}{c}2.10 \% * * * \\
{[1.67 \%]^{* * *}}\end{array}$ & $\begin{array}{c}1.00 \% \\
{[-0.20 \%]}\end{array}$ \\
\hline
\end{tabular}




\section{Table 7}

\section{Effect of financial advisors on bidder CARs}

This table illustrates the wealth effect of financial advisors on bidder announcement cumulative abnormal returns. The sample consists of all successful M\&As by U.S. banking firms, with initial bids announced between January 1, 1984 and December 31, 2015, where complete information about financial advisors could be identified. Bidders are commercial banks with a three-digit primary SIC code equal to 602, or bank holding companies with a four-digit primary SIC code equal to 6712. Targets are comprised of publicly traded, privately-held firms, and unlisted subsidiaries of publicly traded firms. Abnormal returns are estimated using the market adjusted returns model for a five-day event window centered on the announcement date $(-2,+2)$. Panel A segments bidder CARs based on whether the merger was in-house (no investment bank retained) or at least one financial advisor was involved. Panel B segments bidder CARs based on the reputation of the financial advisor employed by the bidding bank. The median CARs are in brackets and the number of mergers is below the medians. The parametric test is the standardized cross-sectional test, and the non-parametric is the Wilcoxon signed rank test. The symbols *, **, and *** denote statistical significance at the $0.10,0.05$ and 0.01 levels respectively, using a 2-tail test.

\begin{tabular}{|c|c|c|c|c|}
\hline & All & Public & Private & Subsidiary \\
\hline \multicolumn{5}{|c|}{ Panel A: All Bids } \\
\hline & $-0.49 \% * * *$ & $-1.75 \% * * *$ & $0.88 \% * * *$ & $0.53 \%$ \\
\hline & {$[-0.66 \%]^{* * *}$} & {$[-1.73 \%]^{* * *}$} & {$[0.43 \%]^{* * *}$} & {$[-0.44 \%]$} \\
\hline & 1055 & 540 & 443 & 72 \\
\hline \multicolumn{5}{|c|}{ Panel B: Financial Advisor } \\
\hline \multirow[t]{3}{*}{ In-house } & $-0.55 \% * *$ & $-0.56 \%$ & $-0.59 \% *$ & $0.60 \%$ \\
\hline & {$[-0.48 \%]^{* *}$} & {$[-1.26 \%]$} & {$[-0.40 \%]$} & {$[0.49 \%]^{* * *}$} \\
\hline & 194 & 61 & 127 & 6 \\
\hline \multirow{3}{*}{$\begin{array}{l}\text { Bidder used } \\
\text { advisor }\end{array}$} & $-0.48 \% * * *$ & $-1.90 \% * * *$ & $1.47 \% * * *$ & $0.52 \%$ \\
\hline & {$[-0.72 \%] * * *$} & {$[-1.81 \%] * * *$} & {$[0.66 \%]^{* * *}$} & {$[-0.44 \%]$} \\
\hline & 861 & 479 & 316 & 66 \\
\hline \multicolumn{5}{|c|}{ Panel C: Reputation of Financial Advisor } \\
\hline \multirow[t]{3}{*}{ Top-Tier } & $-1.57 \% * * *$ & $-2.18 \% * * *$ & $0.07 \%$ & $-0.40 \%$ \\
\hline & {$[-1.67 \%] * * *$} & {$[-2.23 \%] * * *$} & [0.31\%] & {$[-0.44 \%]$} \\
\hline & 261 & 184 & 47 & 30 \\
\hline \multirow[t]{3}{*}{ Non Top-Tier } & $0.00 \%$ & $-1.73 \% * * *$ & $1.72 \% * * *$ & $1.30 \%$ \\
\hline & {$[-0.28 \%]$} & {$[-1.45 \%] * * *$} & {$[0.73 \%]^{* * *}$} & {$[-0.46 \%]$} \\
\hline & 600 & 295 & 269 & 36 \\
\hline
\end{tabular}




\section{Table 8}

\section{OLS regression on bidder CARs}

This table reports the OLS regression results of the bidder's five day CARs for a sample successful M\&As by U.S. banking firms, with initial bids announced between January 1, 1984 and December 31, 2015. All independent variables are defined in the Appendix. All continuous variables are winsorized at 1\% and 99\% level. Significance is based on White (1980) heteroskedasticity consistent standard errors. The t-statistics are reported in parentheses. The symbols *,**, and $* * *$ denote statistical significance at the 0.10 , 0.05 and 0.01 levels respectively, using a 2-tail test.

\begin{tabular}{|c|c|c|c|c|c|c|c|c|c|c|c|c|}
\hline & \multicolumn{3}{|c|}{ All } & \multicolumn{3}{|c|}{ Public } & \multicolumn{3}{|c|}{ Private } & \multicolumn{3}{|c|}{ Subsidiary } \\
\hline & 1 & 2 & 3 & 4 & 5 & 6 & 7 & 8 & 9 & 10 & 11 & 12 \\
\hline \multirow[t]{2}{*}{ Constant } & -0.017 & -0.013 & $-0.030^{*}$ & -0.018 & 0.011 & -0.010 & -0.008 & -0.018 & -0.028 & -0.035 & -0.052 & -0.046 \\
\hline & $(-1.53)$ & $(-0.83)$ & $(-1.65)$ & $(-0.91)$ & $(0.44)$ & $(-0.37)$ & $(-0.62)$ & $(-0.78)$ & $(-1.12)$ & $(-1.02)$ & $(-0.76)$ & $(-0.54)$ \\
\hline \multirow[t]{2}{*}{ State } & 0.001 & 0.005 & $0.006^{*}$ & 0.001 & 0.004 & 0.004 & 0.001 & 0.006 & $0.007 *$ & 0.011 & 0.016 & 0.011 \\
\hline & $(0.67)$ & $(1.60)$ & $(1.81)$ & $(0.26)$ & $(0.90)$ & $(0.91)$ & $(0.41)$ & $(1.35)$ & $(1.66)$ & $(1.21)$ & $(1.01)$ & $(0.67)$ \\
\hline \multirow[t]{2}{*}{ Stock } & 0.001 & 0.001 & 0.000 & -0.003 & -0.003 & -0.003 & 0.001 & -0.001 & -0.001 & 0.003 & -0.014 & -0.027 \\
\hline & $(0.58)$ & $(0.16)$ & $(0.10)$ & $(-0.77)$ & $(-0.42)$ & $(-0.47)$ & $(0.49)$ & $(-0.12)$ & $(-0.09)$ & $(0.26)$ & $(-0.50)$ & $(-0.91)$ \\
\hline \multirow[t]{2}{*}{ Combo } & $-0.005 * *$ & -0.004 & $-0.007 *$ & $-0.012 * *$ & -0.011 & $-0.014 * *$ & -0.003 & 0.001 & -0.003 & 0.000 & -0.006 & -0.008 \\
\hline & $(-1.97)$ & $(-1.01)$ & $(-1.85)$ & $(-2.49)$ & $(-1.64)$ & $(-1.96)$ & $(-1.08)$ & $(0.20)$ & $(-0.56)$ & $(0.01)$ & $(-0.21)$ & $(-0.31)$ \\
\hline \multirow[t]{2}{*}{ RelSize } & $-0.014 * *$ & -0.014 & -0.012 & $-0.018 * *$ & -0.012 & -0.009 & $0.023^{*}$ & 0.026 & $0.031 *$ & -0.006 & 0.017 & 0.029 \\
\hline & $(-1.99)$ & $(-1.59)$ & $(-1.39)$ & $(-2.10)$ & $(-1.23)$ & $(-0.95)$ & (1.78) & $(1.45)$ & (1.69) & $(-0.13)$ & $(0.21)$ & $(0.36)$ \\
\hline \multirow[t]{2}{*}{ Bidder Size } & $-0.001 *$ & -0.001 & -0.000 & -0.001 & -0.000 & -0.000 & -0.001 & 0.000 & 0.001 & 0.005 & 0.004 & 0.001 \\
\hline & $(-1.81)$ & $(-0.45)$ & $(-0.33)$ & $(-0.60)$ & $(-0.22)$ & $(-0.02)$ & $(-0.77)$ & $(0.14)$ & $(0.45)$ & $(0.19)$ & $(0.77)$ & $(0.29)$ \\
\hline \multirow[t]{2}{*}{ Private } & $0.015^{* * *}$ & $0.020 * * *$ & $0.020 * * *$ & & & & & & & & & \\
\hline & $(6.72)$ & $(6.09)$ & $(6.18)$ & & & & & & & & & \\
\hline \multirow[t]{2}{*}{ Subsidiary } & $0.012 * * *$ & $0.012 *$ & $0.013 *$ & & & & & & & & & \\
\hline & $(2.96)$ & $(1.73)$ & (1.79) & & & & & & & & & \\
\hline \multirow[t]{2}{*}{ Volatility } & $0.698 * * *$ & 0.402 & $0.561 * *$ & $0.571 *$ & 0.223 & 0.307 & $0.616^{* *}$ & 0.330 & 0.581 & 1.434 & 1.580 & 1.890 \\
\hline & $(3.67)$ & $(1.43)$ & (1.98) & $(1.70)$ & $(0.50)$ & $(0.68)$ & $(2.55)$ & $(0.85)$ & $(1.48)$ & $(1.53)$ & $(1.08)$ & $(1.42)$ \\
\hline \multirow[t]{2}{*}{ ROA } & 0.002 & -0.002 & -0.000 & 0.002 & -0.004 & -0.003 & 0.001 & 0.000 & 0.005 & 0.007 & -0.003 & -0.003 \\
\hline & $(0.82)$ & $(-0.57)$ & $(-0.02)$ & $(0.60)$ & $(-0.82)$ & $(-0.50)$ & $(0.34)$ & $(0.06)$ & $(0.69)$ & $(0.92)$ & $(-0.18)$ & $(-0.20)$ \\
\hline \multirow[t]{2}{*}{ Pooling } & $-0.009 * * *$ & $-0.012 * * *$ & -0.006 & $-0.015 * * *$ & $-0.019 * * *$ & $-0.016^{* * *}$ & -0.004 & 0.001 & 0.007 & $-0.056^{*}$ & $-0.105^{*}$ & $-0.119 *$ \\
\hline & $(-3.31)$ & $(-2.84)$ & $(-1.50)$ & $(-3.46)$ & $(-3.39)$ & $(-2.68)$ & $(-1.10)$ & $(0.22)$ & (1.13) & $(-1.82)$ & $(-1.71)$ & $(-1.88)$ \\
\hline
\end{tabular}


Table 8 (Continued)

\begin{tabular}{|c|c|c|c|c|c|c|c|c|c|c|c|c|}
\hline & \multicolumn{3}{|c|}{ All } & \multicolumn{3}{|c|}{ Public } & \multicolumn{3}{|c|}{ Private } & \multicolumn{3}{|c|}{ Subsidiary } \\
\hline & 1 & 2 & 3 & 4 & 5 & 6 & 7 & 8 & 9 & 10 & 11 & 12 \\
\hline \multirow[t]{2}{*}{ Advisors } & & $0.007^{*}$ & 0.001 & & $-0.012^{* *}$ & $-0.017 * * *$ & & $0.016^{* * *}$ & $0.011^{*}$ & & -0.011 & -0.031 \\
\hline & & $(1.80)$ & $(0.26)$ & & $(-2.13)$ & $(-2.73)$ & & $(3.27)$ & $(1.88)$ & & $(-0.44)$ & $(-1.06)$ \\
\hline \multirow[t]{2}{*}{ Top-Tier } & & -0.005 & -0.001 & & -0.001 & 0.002 & & -0.009 & -0.004 & & -0.002 & -0.001 \\
\hline & & $(-1.16)$ & $(-0.15)$ & & $(-0.27)$ & $(0.39)$ & & $(-1.43)$ & $(-0.56)$ & & $(-0.14)$ & $(-0.07)$ \\
\hline \multirow[t]{2}{*}{ FIRREA } & $0.009 * * *$ & & 0.011 & $0.016 * *$ & & $0.021 * *$ & $0.008 * *$ & & -0.004 & -0.004 & & 0.016 \\
\hline & $(3.10)$ & & (1.49) & $(2.34)$ & & (2.09) & $(2.33)$ & & $(-0.38)$ & $(-0.30)$ & & $(0.34)$ \\
\hline \multirow[t]{2}{*}{ Riegle-Neal } & 0.001 & & 0.001 & 0.004 & & 0.011 & 0.001 & & -0.016 & -0.008 & & 0.026 \\
\hline & $(0.17)$ & & $(0.17)$ & $(0.47)$ & & $(0.95)$ & $(0.12)$ & & $(-1.53)$ & $(-0.60)$ & & $(0.55)$ \\
\hline \multirow[t]{2}{*}{ GLBA } & $0.010 * * *$ & & $0.017 * *$ & $0.015^{* *}$ & & $0.024 * *$ & $0.00738 * *$ & & 0.001 & 0.006 & & 0.043 \\
\hline & $(3.30)$ & & $(2.24)$ & $(2.27)$ & & $(2.38)$ & $(2.05)$ & & $(0.07)$ & $(0.43)$ & & $(0.93)$ \\
\hline \multirow[t]{2}{*}{ DFA } & $0.021 * * *$ & & $0.026 * * *$ & $0.025 * * *$ & & $0.031 * * *$ & $0.021 * * *$ & & 0.013 & 0.009 & & 0.064 \\
\hline & $(5.65)$ & & $(3.16)$ & $(3.05)$ & & $(2.66)$ & $(5.02)$ & & $(1.28)$ & $(0.42)$ & & $(1.33)$ \\
\hline $\mathrm{N}$ & 2,178 & 1,055 & 1,055 & 790 & 540 & 540 & 1,219 & 443 & 443 & 169 & 72 & 72 \\
\hline Adjusted $R^{2}$ & 0.084 & 0.081 & 0.097 & 0.059 & 0.035 & 0.050 & 0.041 & 0.048 & 0.070 & 0.012 & 0.00 & 0.00 \\
\hline
\end{tabular}




\section{Table 9}

Fixed effects regression on bidder CARs

This table reports the fixed effects regression results of the bidder's five day CARs for a sample successful M\&As by U.S. banking firms, with initial bids announced between January 1, 1984 and December 31, 2015. All independent variables are defined in the Appendix. All continuous variables are winsorized at $1 \%$ and $99 \%$ level. Significance is based on White (1980) heteroskedasticity consistent standard errors. The t-statistics are reported in parentheses. The joint significance of bidder fixed effects (FE) is also reported. The symbols *,**, and *** denote statistical significance at the $0.10,0.05$ and 0.01 levels respectively, using a 2 -tail test.

\begin{tabular}{|c|c|c|c|}
\hline & $(1)$ & $(2)$ & $(3)$ \\
\hline \multirow[t]{2}{*}{ Constant } & -0.009 & -0.004 & 0.017 \\
\hline & $(-0.33)$ & $(-0.12)$ & $(0.46)$ \\
\hline \multirow[t]{2}{*}{ State } & 0.002 & 0.006 & 0.006 \\
\hline & $(0.68)$ & $(1.47)$ & $(1.44)$ \\
\hline \multirow[t]{2}{*}{ Stock } & -0.001 & -0.007 & -0.007 \\
\hline & $(-0.53)$ & $(-1.22)$ & $(-1.28)$ \\
\hline \multirow[t]{2}{*}{ Combo } & $-0.008 * * *$ & $-0.015 * * *$ & $-0.017 * * *$ \\
\hline & $(-2.91)$ & $(-2.76)$ & $(-3.00)$ \\
\hline \multirow[t]{2}{*}{ RelSize } & $-0.026 * * *$ & $-0.029 * * *$ & $-0.031 * * *$ \\
\hline & $(-2.78)$ & $(-2.83)$ & $(-3.00)$ \\
\hline \multirow[t]{2}{*}{ Bidder Size } & 0.000 & 0.002 & -0.004 \\
\hline & $(-0.17)$ & $(0.59)$ & $(-0.99)$ \\
\hline \multirow[t]{2}{*}{ Private } & $0.009 * * *$ & & \\
\hline & $(3.61)$ & & \\
\hline \multirow[t]{2}{*}{ Subsidiary } & 0.005 & & \\
\hline & $(1.02)$ & & \\
\hline \multirow[t]{2}{*}{ Private*Advisors } & & $0.012 * *$ & $0.011 * *$ \\
\hline & & $(2.28)$ & $(2.01)$ \\
\hline \multirow[t]{2}{*}{ Private*Top-Tier } & & -0.003 & -0.002 \\
\hline & & $(-0.44)$ & $(-0.21)$ \\
\hline \multirow[t]{2}{*}{ Subsidiary*Advisors } & & -0.005 & -0.005 \\
\hline & & $(-0.44)$ & $(-0.43)$ \\
\hline \multirow[t]{2}{*}{ Subsidiary*Top-Tier } & & -0.006 & -0.006 \\
\hline & & $(-0.35)$ & $(-0.37)$ \\
\hline \multirow[t]{2}{*}{ Volatility } & $0.508 * *$ & 0.174 & 0.349 \\
\hline & $(1.98)$ & $(0.36)$ & $(0.70)$ \\
\hline \multirow[t]{2}{*}{ ROA } & -0.001 & -0.008 & -0.004 \\
\hline & $(-0.28)$ & $(-1.24)$ & $(-0.50)$ \\
\hline \multirow[t]{2}{*}{ Pooling } & $-0.010 * * *$ & $-0.009 * *$ & -0.007 \\
\hline & $(-3.39)$ & $(-1.97)$ & $(-1.45)$ \\
\hline \multirow[t]{2}{*}{ FIRREA } & $0.007 *$ & & $0.019 * *$ \\
\hline & $(1.86)$ & & $(2.03)$ \\
\hline \multirow[t]{2}{*}{ Riegle-Neal } & -0.001 & & 0.012 \\
\hline & $(-0.12)$ & & $(1.22)$ \\
\hline \multirow[t]{2}{*}{ GLBA } & 0.006 & & $0.025 * *$ \\
\hline & $(0.88)$ & & $(2.27)$ \\
\hline \multirow[t]{2}{*}{ DFA } & $0.019 * *$ & & $0.035 * * *$ \\
\hline & $(2.34)$ & & $(2.70)$ \\
\hline Number of unique bidders & 506 & 392 & 392 \\
\hline Bidder FE $F$-test & $1.452 * * *$ & $1.258 * * *$ & $1.239 * * *$ \\
\hline $\mathrm{N}$ & 2,178 & 1,055 & 1,055 \\
\hline Adjusted $R^{2}$ & 0.172 & 0.168 & 0.174 \\
\hline
\end{tabular}




\section{Table 10}

Heckman two-stage procedure on bidder CARs

This table reports the results of the Heckman two-stage procedure for bidder five day CARs for a sample successful M\&As by U.S. banking firms, with initial bids announced between January 1, 1984 and December 31, 2015. The first column of each set of models is the first-stage equations estimated by probit regressions, in which the dependent variable is 1 if the target firm was private and 0 if it was public. The second column of each set of models is the second-stage equations estimated by OLS regressions, where the dependent variable is the bidder CARs for private bids, and the Inverse Mills ratio accounts for the presence of selection bias. All independent variables are defined in the Appendix. All continuous variables are winsorized at $1 \%$ and $99 \%$ level. Significance is based on White (1980) heteroskedasticity consistent standard errors. The t-statistics are reported in parentheses. The symbols *, $*^{*}$, and $* * *$ denote statistical significance at the $0.10,0.05$ and 0.01 levels respectively, using a 2-tail test.

\begin{tabular}{|c|c|c|c|c|c|c|}
\hline & Probit & OLS & Probit & OLS & Probit & OLS \\
\hline & \multicolumn{2}{|c|}{ (1) } & \multicolumn{2}{|c|}{ (2) } & \multicolumn{2}{|c|}{ (3) } \\
\hline Constant & $\begin{array}{c}6.523 * * * \\
(15.84)\end{array}$ & $\begin{array}{l}-0.003 \\
(-0.08)\end{array}$ & $\begin{array}{c}5.853 * * * \\
(10.23)\end{array}$ & $\begin{array}{l}-0.025 \\
(-0.45)\end{array}$ & $\begin{array}{c}6.077 * * * \\
(9.36)\end{array}$ & $\begin{array}{l}-0.031 \\
(-0.52)\end{array}$ \\
\hline State & $\begin{array}{c}-0.151 * * \\
(-2.08)\end{array}$ & $\begin{array}{l}0.001 \\
(0.37)\end{array}$ & $\begin{array}{c}-0.352 * * * \\
(-3.33)\end{array}$ & $\begin{array}{l}0.007 \\
(1.32)\end{array}$ & $\begin{array}{c}-0.352 * * * \\
(-3.32)\end{array}$ & $\begin{array}{l}0.008 \\
(1.52)\end{array}$ \\
\hline Stock & $\begin{array}{c}-0.490 * * * \\
(-4.78)\end{array}$ & $\begin{array}{l}0.001 \\
(0.37)\end{array}$ & $\begin{array}{c}-0.607 * * * \\
(-3.81)\end{array}$ & $\begin{array}{l}0.002 \\
(0.24)\end{array}$ & $\begin{array}{c}-0.591 * * * \\
(-3.70)\end{array}$ & $\begin{array}{l}0.002 \\
(0.21)\end{array}$ \\
\hline Combo & $\begin{array}{c}-0.387 * * * \\
(-3.53)\end{array}$ & $\begin{array}{l}-0.003 \\
(-0.92)\end{array}$ & $\begin{array}{c}-0.475^{* * *} \\
(-3.05)\end{array}$ & $\begin{array}{l}0.002 \\
(0.37)\end{array}$ & $\begin{array}{c}-0.396^{* *} \\
(-2.45)\end{array}$ & $\begin{array}{l}-0.002 \\
(-0.32)\end{array}$ \\
\hline RelSize & $\begin{array}{c}-4.067 * * * \\
(-12.23)\end{array}$ & $\begin{array}{l}0.015 \\
(0.53)\end{array}$ & $\begin{array}{c}-3.143 * * * \\
(-10.03)\end{array}$ & $\begin{array}{l}0.024 \\
(0.57)\end{array}$ & $\begin{array}{c}-3.203 * * * \\
(-9.87)\end{array}$ & $\begin{array}{l}0.025 \\
(0.59)\end{array}$ \\
\hline Bidder Size & $\begin{array}{c}-0.503 * * * \\
(-15.81)\end{array}$ & $\begin{array}{l}-0.001 \\
(-0.42)\end{array}$ & $\begin{array}{c}-0.499 * * * \\
(-10.39)\end{array}$ & $\begin{array}{l}0.001 \\
(0.20)\end{array}$ & $\begin{array}{c}-0.503 * * * \\
(-10.34)\end{array}$ & $\begin{array}{l}0.001 \\
(0.23)\end{array}$ \\
\hline Volatility & $\begin{array}{l}3.404 \\
(0.54)\end{array}$ & $\begin{array}{c}0.589 * * \\
(2.42)\end{array}$ & $\begin{array}{l}8.672 \\
(1.10)\end{array}$ & $\begin{array}{l}0.245 \\
(0.63)\end{array}$ & $\begin{array}{l}7.931 \\
(0.96)\end{array}$ & $\begin{array}{l}0.510 \\
(1.29)\end{array}$ \\
\hline ROA & $\begin{array}{l}-0.080 \\
(-0.78)\end{array}$ & $\begin{array}{l}0.001 \\
(0.30)\end{array}$ & $\begin{array}{l}-0.091 \\
(-0.71)\end{array}$ & $\begin{array}{l}0.001 \\
(0.11)\end{array}$ & $\begin{array}{l}-0.078 \\
(-0.59)\end{array}$ & $\begin{array}{l}0.004 \\
(0.64)\end{array}$ \\
\hline Pooling & $\begin{array}{c}-0.160^{*} \\
(-1.67)\end{array}$ & $\begin{array}{l}-0.004 \\
(-1.07)\end{array}$ & $\begin{array}{l}-0.062 \\
(-0.49)\end{array}$ & $\begin{array}{l}0.001 \\
(0.18)\end{array}$ & $\begin{array}{l}-0.128 \\
(-0.90)\end{array}$ & $\begin{array}{c}0.007 \\
(1.120)\end{array}$ \\
\hline FIRREA & $\begin{array}{c}-0.585^{* * * *} \\
(-4.53)\end{array}$ & $\begin{array}{l}0.008 \\
(1.57)\end{array}$ & & & $\begin{array}{c}-0.146 \\
(-0.530)\end{array}$ & $\begin{array}{l}-0.004 \\
(-0.40)\end{array}$ \\
\hline Riegle-Neal & $\begin{array}{c}-0.566 * * * \\
(-3.70)\end{array}$ & $\begin{array}{l}0.000 \\
(0.01)\end{array}$ & & & $\begin{array}{l}-0.213 \\
(-0.72)\end{array}$ & $\begin{array}{l}-0.016 \\
(-1.46)\end{array}$ \\
\hline GLBA & $\begin{array}{c}-0.856^{* * *} \\
(-6.26)\end{array}$ & $\begin{array}{l}0.007 \\
(1.12)\end{array}$ & & & $\begin{array}{l}-0.401 \\
(-1.41)\end{array}$ & $\begin{array}{l}0.001 \\
(0.08)\end{array}$ \\
\hline DFA & $\begin{array}{c}-0.854 * * * \\
(-5.47)\end{array}$ & $\begin{array}{c}0.021 * * * \\
(3.13)\end{array}$ & & & $\begin{array}{l}-0.403 \\
(-1.38)\end{array}$ & $\begin{array}{c}0.0132 \\
(1.07)\end{array}$ \\
\hline Advisors & & & $\begin{array}{c}-0.445 * * * \\
(-3.14)\end{array}$ & $\begin{array}{c}0.019 * * * \\
(2.77)\end{array}$ & $\begin{array}{c}-0.328 * * \\
(-2.17)\end{array}$ & $\begin{array}{c}0.0127 * * \\
(2.07)\end{array}$ \\
\hline Top-Tier & & & $\begin{array}{l}0.034 \\
(0.25)\end{array}$ & $\begin{array}{l}-0.008 \\
(-1.22)\end{array}$ & $\begin{array}{l}-0.065 \\
(-0.46)\end{array}$ & $\begin{array}{l}-0.003 \\
(-0.40)\end{array}$ \\
\hline Inverse Mills Ratio & & $\begin{array}{l}0.001 \\
(0.04)\end{array}$ & & $\begin{array}{l}-0.007 \\
(-0.31)\end{array}$ & & $\begin{array}{l}-0.005 \\
(-0.25)\end{array}$ \\
\hline $\begin{array}{l}\mathrm{N} \\
\left.\text { Pseudo- } R^{2} \text { (Adjusted } R^{2}\right)\end{array}$ & $\begin{array}{l}2,009 \\
0.279\end{array}$ & $\begin{array}{c}1,219 \\
(0.037)\end{array}$ & $\begin{array}{c}983 \\
0.294\end{array}$ & $\begin{array}{c}443 \\
(0.041)\end{array}$ & $\begin{array}{c}983 \\
0.297\end{array}$ & $\begin{array}{c}443 \\
(0.061)\end{array}$ \\
\hline
\end{tabular}

